\title{
What do people value in urban green? Linking characteristics of urban green spaces to users' perceptions of nature benefits, disturbances, and disservices
}

\author{
Julia Palliwoda ${ }^{1}$ and Joerg A. Priess ${ }^{1}$
}

\begin{abstract}
Now, and in the future, the majority of the world's population is and will be living in cities. Thus, efficient urban green spaces (UGS), such as urban parks providing ecosystem services, are essential for human well-being. Besides their location, the characteristics of UGS, for example, size, availability of facilities (such as sports infrastructure or benches), and green characteristics, can determine the benefits derived or disturbances and disservices perceived by visitors. Knowing which components of UGS contribute to which benefits can help to meet the various demands of urban dwellers. The objective of this research is to present positive and negative aspects (benefits and disturbances/disservices, respectively) of UGS that people perceive and the difference in these perceptions across age groups and UGS. We surveyed more than 1700 users of 18 urban parks and 18 brownfields in Leipzig, Germany. Benefits related to natural elements and landscape aesthetics were most important especially for older age groups. Younger people placed more importance on size, availability, and location as well as sports facilities. The most frequently mentioned disturbance/disservice in urban parks was litter followed by the undesirable activities of other users. Tree cover, sports facilities, seating possibilities, and inhabitant density in the neighborhood influenced the perception of parks providing regulating services (noise mediation and shade provision) and social and cultural interactions. Brownfields were often appreciated as additional UGS close to people's homes and for their wilderness aspects. Implementing specific facilities and varying tree cover can influence perceived benefits from UGS. Adapted management measures can therefore increase multiple benefits and minimize trade-offs between UGS users and uses, for example, the integration of wild areas into UGS including low or near-natural management areas.
\end{abstract}

Key Words: brownfields; ecosystem services; trade-offs; urban parks

\section{INTRODUCTION}

International, national, and local policy guidelines call for the development of sustainable cities because the majority of the world's population is and will be increasingly living in urban areas (Bundesregierung 2016, Stadt Leipzig 2017a, United Nations 2017). Urban green spaces (UGS) such as urban parks and forests as well as unmaintained, informal sites like brownfields and vacant lots are considered fundamental points on the road to urban sustainability because they provide essential ecosystem services (Bolund and Hunhammer 1999, Elmqvist et al. 2015) promoting human health and well-being (de Vries et al. 2003, Tzoulas et al. 2007).

Ecosystem services provided by UGS range from habitat supply to provisioning and regulating services to cultural services (MEA 2005, Gómez-Baggethun and Barton 2013). Although urban food supply as a provisioning service plays a minor role in cities, studies do underline its potential for global food security as in Eigenbrod and Gruda (2015), Russo et al. (2017). Important regulating services in cities are, for example, the regulation of urban temperature or noise reduction by vegetation (Bolund and Hunhammer 1999, Gómez-Baggethun and Barton 2013). Furthermore, UGS in the form of urban parks provide space for recreation, physical exercise, and social interactions for city residents (Peters et al. 2010, Gómez-Baggethun and Barton 2013, Krellenberg et al. 2014). They offer opportunities to experience and interact with nature (Gobster and Westphal 2004, Palliwoda et al. 2017) and provide aesthetical as well as educational values (Bertram and Rehdanz 2015). These cultural services are highly relevant in UGS because they directly contribute to the physical and psychological well-being of people (Tzoulas et al. 2007, Kessel et al. 2009, Lee and Maheswaran 2011). The actual flow or use of these ecosystem services and benefits that are (potentially) provided by UGS is determined by their accessibility and UGS characteristics as well as by preferences and socialdemographic characteristics of users, i.e. urban residents (Hegetschweiler et al. 2017). Urban green spaces should therefore include appropriate features and facilities and should be accessible for users to facilitate their benefits.

Urban parks represent perfect examples of highly managed and well-maintained urban ecosystems and thus a typical type of UGS. Physical activities and the flow of benefits and ecosystem services increase with safe and well-kept parks within close distance from people's home (Bird 2004, Toftager et al. 2011, Schipperijn et al. 2013, Langemeyer and Connolly 2020). Several guidelines and thresholds have been provided by researchers and city planners suggesting UGS within $250-300$ m from people's place of living (Barbosa et al. 2007, Toftager et al. 2011, Stadt Leipzig 2017b). Plenty of studies underline a minimum size of (the nearest) UGS as an important use-determining factor revealing that large UGS are used more frequently (Giles-Corti et al. 2005, Schipperijn et al. 2013, Hegetschweiler et al. 2017). Still, small parks in dense neighborhoods can be especially important for social interactions (Peschardt and Stigsdotter 2013) and may be used for other cultural ecosystem services than large urban parks (Van Herzele and Wiedemann 2003, Nordh et al. 2011, Wright Wendel et al. 2012). As a counterpart to wellmaintained urban parks, green brownfields characterized by ecological succession can provide additional space not only for recreational activities such as meeting people and dog walking (Rall and Haase 2011, Pueffel et al. 2018) but also for nature experiences and "urban wilderness" (Kowarik 2005). Hence, urban brownfields should be considered as important elements 
of green space in cities and their benefits to people need to be identified (Mathey et al. 2015, Banzhaf et al. 2018).

Distance and size (which we refer to as "spatial characteristics" in this study) are not the only factors influencing UGS use (Van Herzele and Wiedemann 2003). Several studies analyzed the importance of facilities available for physical activities in UGS and found, for example, positive influences of trails, lighting, sports infrastructure, and benches (Kaczynski and Henderson 2008, Kaczynski et al. 2008, Schipperijn et al. 2013, Voigt et al. 2014, Schetke et al. 2016). In addition to these "gray characteristics," biotic features like biological diversity or trees, which we refer to here as "green characteristics," are affecting UGS use and activities (Voigt et al. 2014, Palliwoda et al. 2020). Urban green space visitors place importance on the presence of large trees, wooded areas, and general greenness and naturalness (Giles-Corti et al. 2005, Kaczynski et al. 2008, Bijker and Sijtsma 2017). Studies furthermore found positive relationships between actual or perceived plant species richness of UGS and the psychological well-being of their users (Fuller et al. 2007, Dallimer et al. 2012).

Besides characteristics of the UGS itself, there are differences in preferences, use frequencies, and motives across different demographic groups. For instance, older people prefer less dense vegetation structures in urban parks (Bjerke et al. 2006) and perceive urban brownfields with spontaneous vegetation in Leipzig and Dresden (Germany) more positively than younger people (Mathey et al. 2016). Older age groups more often prefer parks for nature-related activities and place more importance on aesthetical values and landscape characteristics than younger people (Chiesura 2004, Kienast et al. 2012, Shan 2014, Ode Sang et al. 2016).

These findings from the literature underline the heterogeneous framework of factors influencing ecosystem service and benefit provision on the one hand and the actual use of them by urban residents on the other hand, which is influenced by their individual preferences. Knowledge about which characteristics of UGS affect the benefits to individuals with different demographic backgrounds is therefore urgently needed to improve UGS design (Kremer et al. 2016, Hegetschweiler et al. 2017).

In addition to benefits, UGS can include aspects that can be perceived negatively ranging from man-made (waste, vandalism) to (partly) natural (allergenic plants, mosquitos, or intruding animals), which we refer to here as "disturbances/disservices" (Lyytimäki et al. 2008, Plieninger et al. 2013). In existing studies, disturbances of UGS are often limited to the analysis of healthrelated ecosystem disservices like allergenic potential (D'Amato 2000, Ćwik et al. 2018, Battisti et al. 2019) and air quality issues (Gómez-Baggethun and Barton 2013), or safety issues caused by dense vegetation structures and poor lighting in UGS (Koskela and Pain 2000, Hami and Emami 2015). In addition to healthrelated and safety issues, some activities in UGS can be disturbing for other users and the creation and management of UGS providing multiple ES can thus be very challenging for planners (Tzoulas and James 2010, Liu et al. 2018). Some benefits can coexist and create synergistic ecosystem service provision, meaning that two or more ecosystem services support each other or even increase simultaneously. On the other hand, others may create trade-offs (two benefits impair each other: one decreases while the other increases) or are perceived as disturbing by different social-demographic and cultural groups (Haase et al. 2012, Gómez-Baggethun and Barton 2013, Kremer et al. 2016). A study in Finland, for instance, showed that older persons felt more disturbed by public nuisance and littering of a seashore in Helsinki than younger people (Lodenius 2004). Another example from Sheffield, UK revealed older age groups feeling more concerned about their reduced mobility causing security risks and placing more importance on easily accessible UGS than younger persons (Jorgensen and Anthopoulou 2007).

The main aim of this research is to understand perceived benefits and disturbances/disservices that people of different age groups discern on two types of UGS: urban parks and brownfields. Additionally, we tested the influence of selected UGS characteristics on the most frequently mentioned nature benefits. Given the findings from other studies mentioned above, we hypothesized that nature benefits, which urban inhabitants derive from urban parks, are influenced by various factors referring to the park's green, gray, and spatial components. We furthermore assumed that perception is related to people's age and thus may change during the lifetime of UGS users. Knowing which components of UGS contribute to which benefits can improve the development and management of UGS, better meeting the multiple demands of their users.

This paper addresses the following research questions:

1. Which benefits as well as disturbances and disservices are perceived by park and brownfield users across different age groups?

2. Which green, spatial, and gray UGS characteristics may influence perceptions?

\section{METHODS AND MATERIAL}

\section{Study area and study site selection}

The study area was located in the city of Leipzig, one of the fastest growing cities in Germany with an area of about 30,000 ha. The city has experienced a shrinkage process and is now facing growing inhabitant numbers, which makes it an interesting case study because of the transition of contrasting land-use pressures. After the German reunification in 1990, Leipzig was affected by massive economic and population declines, which led to thousands of abandoned plots (brownfields) all over the city (Haase 2008). Residential and industrial buildings were demolished, and the city applied various development strategies such as the development of nature protection sites, new green spaces, and interim-use strategies to account for the large number of vacant sites (Rall and Haase 2011, Mathey and Rink 2020). Contrastingly, since the year 2012, the population has been continuously increasing by approximately 10,000 people per year, reaching more than 600,000 inhabitants in 2020 (Stadt Leipzig 2020). Population growth is driven mainly by young people under the age of 30 , who prefer to move to districts close to the city center, which are often characterized by low availability of green areas (Stadt Leipzig 2019). Remaining vacant sites and brownfields are now hotspots for urban development projects, including the development of new UGS that support climate change adaption and recreation but also provide areas for facilitating housing, education, and transport (Stadt Leipzig 2017b). Most of the city's brownfields 
are covered by vegetation and undergo natural ecological succession. Some of them are grassy areas managed by residents or private owners (Fig. 1). All unused spaces regardless of their ownership or former use in Leipzig are registered by the city and defined as brownfields (Stadt Leipzig 2017c). Brownfields can provide space for recreational activities (Pueffel et al. 2018, Palliwoda et al. 2020) and offer, due to their undisturbed development, valuable habitats for several plant and animal species, including red-listed (endangered) species (Muratet et al. 2007, Kowarik 2013, Mathey et al. 2015) and thus complement the city's more formal and maintained types of UGS. Furthermore, Leipzig provides plenty of public green recreational areas (about $11 \%$ of the total city area), water structures (4\%), and forest areas (about 7\%), the latter mainly consisting of riparian forests running from the north-west to the south-west of the city.

Fig. 1. Study sites in the city of Leipzig. We selected 18 urban parks (green) and 18 brownfields (blue) in a $5 \mathrm{~km}$ radius from the city center. Photos on the right show examples of green brownfields in Leipzig with varying tree cover. More photos of brownfields and urban parks can be found in Appendix 1 (Figures A1.1-A1.6). Map source: OpenStreetMap and contributors; Photos: J. Palliwoda.



For this study, we chose two different but typical types of UGS to reflect their variety and to consider the range of benefits they provide. We selected urban parks and green brownfields (i.e., brownfields with vegetation) within $5 \mathrm{~km}$ from the city center. Tree cover (trees $\geq 5 \mathrm{~m}$ in height) of every park and brownfield was determined on the basis of analyzed digital orthophotos from June 2012 and a digital surface model from 2010. Data of tree cover were kindly provided by E. Banzhaf (Banzhaf et al. 2020). Tree cover was divided into three classes: low $(0-33 \%$ of the area is covered by trees), medium (> 33-67\%), and high (> 67-100\%). This data enabled a stratified random sampling of study sites (UGS type: park or green brownfield; tree cover: low, medium, high). The random selection of six replicates of each group resulted in 18 parks and 18 green brownfields of 3 tree cover classes to ensure an even tree cover distribution (see Appendix 1, Table A1.1). The sole precondition for green brownfields was that they were accessible, i.e., not completely surrounded by walls or fences nor completely overgrown by shrubs, which was preverified during field visits before final study site selection. Due to natural ecological succession and tree growth, most brownfields and urban parks in Leipzig fall within the medium and high tree cover classes. Figure 1 shows all final study sites and photos of some brownfields with different tree cover in Leipzig.

\section{Survey about ecosystem service use and perceived benefits and disturbances/disservices}

Our approach combined a structured observation to count user density and a survey with randomly selected respondents about ecosystem service use and perceived benefits and disturbances/ disservices of study sites. Observation and surveys with randomly selected visitors were conducted on all 36 study sites. Results from the observations are not analyzed in this study (see Palliwoda et al. 2020 for analysis of observed use density). Every site was visited eight times covering each of the four time slots twice: morning (8-11), noon (11-14), afternoon (14-17), and evening $(17-20)$. For the survey, visitors entering the observation unit were chosen randomly during observations (asking adult persons every fifth minute). Observation units were delineated by visual or other barriers like paths, shrubs, or walls. Visitors that appeared younger than 14 years were only interviewed when in company of adults (ADM 2021). From the 18 observed brownfields, only 14 were visited by people. Three brownfields that were not used at all were sites with high tree cover and one with medium tree cover. On one further brownfield with high tree cover, we observed drug use and dealing, and as such, no interviews were conducted there. Hence, our survey results for brownfields represent mainly sites with medium and low tree cover $\left(n_{\text {total }}=13\right)$. Surveys and observations were pretested on one brownfield and one park in April 2018 and then conducted between mid-April and September 2018 by the first author supported by a well-trained scientific assistant (MSc). Data were collected on weekdays and weekends and only during fair weather conditions.

Our written questionnaire was based on the smartphone application MapNat (MapNat is available at Google and Apple playstores and has been refined during this study, funded by the UrbanGaia project; Project number 01LC1616A) and set up in German (translated survey in Appendix 1). Respondents mainly preferred oral questions read to them by the interviewer. The survey included 24 selectable ecosystem services potentially relevant for UGS use. Respondents were asked to choose one ecosystem service that they were using at that time, followed by additional questions about use frequency, importance, and motivation (see Palliwoda et al. 2020 for detailed analysis of ecosystem service use and motivation). The question about positive and negative aspects (benefits and disturbances/ disservices, respectively) was an open-ended question with the following two subquestions: "What do you like about this site? What do you dislike or feel disturbed by?" Finally, we asked respondents about age and gender and their place of residence or, if people were taking (lunch) breaks, their work place (street and postcode).

For the analysis, we assigned answers of the open-ended questions to keywords or key parameters, which were then aggregated into categories (Table 1). We differentiated all generated positive categories into two benefit types: gray benefits (spatial or infrastructure-related park features, comments regarding maintenance, or use regulations) and nature benefits (categories that refer to contributions of nature to people in terms of 
Table 1. Categories of benefits and their (partly) contradicting disturbances perceived by respondents in urban parks and brownfields. Several answers were possible. Answers by respondents mentioning several keywords within one category (e.g., flowering aspects and trees) were counted as one.

\begin{tabular}{|c|c|c|c|c|}
\hline & Benefit categories & Keywords/key parameters & $\begin{array}{l}\text { Disturbance/disservice } \\
\text { categories }\end{array}$ & Keywords/key parameters \\
\hline \multirow[t]{6}{*}{$\begin{array}{l}\text { Nature } \\
\text { benefits }\end{array}$} & $\begin{array}{l}\text { Environmental education } \\
\text { and gardening } \\
\text { Green landscape/aesthetics }\end{array}$ & $\begin{array}{l}\text { Environmental education, identification } \\
\text { tags on plants, urban gardening activities } \\
\text { Beautiful landscape, green landscape, } \\
\text { green or nature as a whole, experience } \\
\text { nature }\end{array}$ & & \\
\hline & Natural elements & $\begin{array}{l}\text { Reference to elements of nature: trees, } \\
\text { flowering aspects, animals, water/pond, } \\
\text { meadow }\end{array}$ & Little/no nature & $\begin{array}{l}\text { No, not enough trees/flowering aspects or } \\
\text { vegetation/green, dry/yellow vegetation }\end{array}$ \\
\hline & $\begin{array}{l}\text { Regulating ecosystem } \\
\text { services }\end{array}$ & Shade, quiet/noise reduction & Noise/little shade & $\begin{array}{l}\text { No/not enough shade, hearing noise from } \\
\text { surrounding streets }\end{array}$ \\
\hline & Sense of place & $\begin{array}{l}\text { Sense of place, history of park, cultural } \\
\text { heritage }\end{array}$ & & \\
\hline & $\begin{array}{l}\text { Social and cultural } \\
\text { interactions }\end{array}$ & $\begin{array}{l}\text { Meeting point, other people, initiatives, } \\
\text { children/family, intercultural exchange, } \\
\text { neighborhood initiatives, events, } \\
\text { possibilities to barbeque }\end{array}$ & Other users/behavior/bicycles & $\begin{array}{l}\text { Feeling disturbed by (groups of) other } \\
\text { persons (e.g., teenagers, people from other } \\
\text { cultures) or events, fast bicycles, other } \\
\text { people barbecuing and causing smoke or } \\
\text { leaving trash, too many people }\end{array}$ \\
\hline & Urban wilderness & $\begin{array}{l}\text { Nature-like, near-natural conditions, no/ } \\
\text { low maintenance, wilderness aspects, } \\
\text { discover }\end{array}$ & & \\
\hline \multirow[t]{10}{*}{$\begin{array}{l}\text { Gray } \\
\text { benefits }\end{array}$} & Art and buildings & $\begin{array}{l}\text { Graffiti, statues, buildings, monuments } \\
\text { (for brownfields: available infrastructure) }\end{array}$ & & \\
\hline & Dog friendly & $\begin{array}{l}\text { Suitable site for dogs: fenced, possibility } \\
\text { to let dogs off the leash, designated dog } \\
\text { areas, other dog infrastructure }\end{array}$ & Dogs & $\begin{array}{l}\text { Feeling disturbed or scared by dogs, dog } \\
\text { litter }\end{array}$ \\
\hline & Freedom/no regulations & $\begin{array}{l}\text { No regulatory agency, no regulations, } \\
\text { freedom, move freely }\end{array}$ & Safety/crime & $\begin{array}{l}\text { Alcohol abuse/people drinking alcohol, } \\
\text { drug dealing, lack of/poor lighting, feeling } \\
\text { unsafe }\end{array}$ \\
\hline & & & Vandalism & Graffiti, broken/tagged benches \\
\hline & Infrastructure & Benches, paths, playgrounds & Missing/bad infrastructure & $\begin{array}{l}\text { Not enough/missing infrastructure or } \\
\text { services (e.g., benches, toilets, kiosk) }\end{array}$ \\
\hline & $\begin{array}{l}\text { Park design and } \\
\text { maintenance }\end{array}$ & $\begin{array}{l}\text { (Architectural) design of the site, safety, } \\
\text { cleanliness, maintenance, open view }\end{array}$ & $\begin{array}{l}\text { Unsuitable design and } \\
\text { maintenance }\end{array}$ & $\begin{array}{l}\text { Not enough meadow, unsightly design, site } \\
\text { is too small, not enough space, lacking or } \\
\text { poor maintenance of vegetation or water } \\
\text { bodies }\end{array}$ \\
\hline & & & Litter/waste & Too much litter/waste, missing waste bins \\
\hline & Seclusion & $\begin{array}{l}\text { No other people/not so crowded, } \\
\text { tranquility, escape }\end{array}$ & & \\
\hline & Sports facilities & $\begin{array}{l}\text { Table tennis, fitness, running tracks, } \\
\text { beach volleyball, basketball, football }\end{array}$ & & \\
\hline & $\begin{array}{l}\text { Size/availability and } \\
\text { location }\end{array}$ & $\begin{array}{l}\text { Size, proximity, central location, } \\
\text { accessibility, "good to have it there" }\end{array}$ & Potential loss & $\begin{array}{l}\text { Removal/future building development of } \\
\text { site }\end{array}$ \\
\hline
\end{tabular}

aesthetical, spiritual, recreational, and intellectual values, the physical dimension of nature/nature itself as well as regulating ecosystem services such as microclimate regulation (MEA 2005, Haines-Young and Potschin 2013, Díaz et al. 2015)). Disturbances/disservices, which contradicted a benefit category, were grouped with that category illustrating individual and partly opposite perceptions of similar aspects among respondents (Table 1 ). We then counted the number of responses per category in each of the 18 parks and the 13 brownfields where people were interviewed.

\section{Urban green space (UGS) characteristics}

To identify UGS characteristics that might influence perceived benefits, we selected characteristics that represent three key structural dimensions of UGS: green, spatial, and gray characteristics (Voigt et al. 2014, Hegetschweiler et al. 2017). In addition to the three green characteristics, tree cover (Kaczynski et al. 2008, Timperio et al. 2008, Hofmann et al. 2012), richness of tree species, and richness of flowering species (Fuller et al. 2007, Dallimer et al. 2012), size, and inhabitant density within $300 \mathrm{~m}$ (Van Herzele and Wiedemann 2003, Wright Wendel et al. 2012) were selected as spatial characteristics. For gray characteristics of UGS, we selected seating possibilities as important park amenities supporting passive or resting relaxation (McCormack et al. 2010, Voigt et al. 2014), the presence of lighting contributing to safety (Giles-Corti et al. 2005), and the presence of sports facilities for active physical interactions (Gearin and Kahle 2006, Ries et al. 2008, McCormack et al. 2010). Figure 2 visualizes UGS characteristics of each structural dimension that were assessed in each of the 36 study sites. 
Fig. 2. Measured urban green space (UGS) characteristics of three structural dimensions (green, spatial, and gray) in 18 urban parks and 18 green brownfields.

\begin{tabular}{l}
\hline Green \\
characteristics \\
Tree cover $(\%)$ \\
Tree richness $\left(\right.$ species $\left./ 100 \mathrm{~m}^{2}\right)$ \\
Flowering richness $\left(\right.$ species $\left./ 100 \mathrm{~m}^{2}\right)$ \\
\hline
\end{tabular}

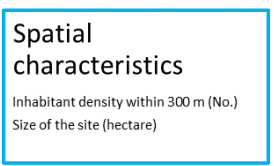

\begin{tabular}{|l|}
\hline Gray \\
characteristics \\
Lighting (No./hectare) \\
Seating possibilities(No./hectare) \\
Sports facilities (No.) \\
\hline
\end{tabular}

Tree cover is defined as the proportion of the study site that is covered by trees $\geq 5 \mathrm{~m}$ in height. For assessing species richness, we used ArcGIS (version 10.6) to generate randomly distributed points representing the center of $15 \times 15 \mathrm{~m}$ sample plots on all study sites and covering at least $1 \%$ of the total area of each study site (Hermy and Cornelis 2000). Within these plots, we identified all woody species at or above 5 meters in height for tree richness as well as all herbaceous species that were flowering at the time of mapping (August-September 2017). The authors are aware that species assessments may not cover the whole range of species richness on study sites. To avoid underrepresentation of species, especially in small parks and brownfields, we set up a minimum of two sample plots and furthermore mapped all present tree species on brownfields that were smaller than the smallest park $(<0.65 \mathrm{ha})$. Species richness was then scaled to species per 100 $\mathrm{m}^{2}$.

Spatial characteristics comprised the density of the human population within $300 \mathrm{~m}$ of the edge of each study site as well as the size of the sites. We calculated the number of inhabitants in a $300 \mathrm{~m}$ Euclidian distance surrounding each UGS site based on a dataset provided by the city of Leipzig (Stadt Leipzig 2018). The distance of $300 \mathrm{~m}$, representing a walking time of 5 minutes, is frequently used to analyze access to UGS (Barbosa et al. 2007, Toftager et al. 2011).

Infrastructural features and facilities were defined as gray characteristics. At each site, we counted all available permanent seating possibilities (benches, attached chairs, etc.), lights and sports facilities (table tennis, basketball or soccer field, running tracks, etc.). Gray characteristics were counted in summer 2017 and seating possibilities and lights were scaled to units per hectare.

All green, spatial, and gray characteristics of each study site can be found in Appendix 1, Table A1.1.

\section{Data analysis}

Data were processed in R version 3.6.1, MAXQDA version 12.1.3, and ArcGIS version 10.6. Survey data were translated into English language, statistical analysis was carried out with the "stats" package (R Core Team 2020), and data visualization with the "ggplot2" package (Wickham 2016).

\section{Demographic characteristics of respondents}

Respondents were grouped into the following age groups: children and teenagers $(<18 \mathrm{y})$, young adults $(18-30 \mathrm{y})$, adults (31-64 y), and older persons (65+ y; Jim and Chen 2006). The analysis of perceived benefits and disturbances excluded children and teenagers, because for children we recorded the same aspects their parent or guardian mentioned. We then counted the frequency of each perceived benefit and disturbance/disservice across age groups. To determine significant differences of frequencies in perceived benefits and disturbances/disservices between age groups in urban parks, we applied the chi-square test of independence. Sample sizes for older persons were too low on brownfields and thus age differences are not statistically tested for this UGS type. We located the home or work place address of respondents with the geo-referencing tool in ArcGIS (averaged from street and postcode). To calculate the distance between addresses and UGS sites, we used the Network Analyst tool of ArcGIS, calculating the shortest route from the estimated place of living or work to the nearest point of the circumference or nearest entrance of the site.

\section{Interaction of benefits and influence of park characteristics}

To analyze spatial correlations between pairs of all benefits (nature and gray benefits) on each study site, the weighted Spearman's rank correlation test was applied separating urban parks from brownfields (weight $=$ number of surveys on each study site). For this analysis, we calculated the frequency of answers for each benefit for each urban park and brownfield and applied the correlation test for these frequencies. To confirm robustness of correlation coefficients, bootstrapping with 1000 resamples of study sites was applied to calculate upper and lower quartiles (0.95 and 0.05; Appendix 1, Tables A1.4, A1.5). Positive values of correlations coefficients imply that two benefits are positively influencing each other (synergies), negative values imply trade-offs.

To statistically test the influence of UGS characteristics on the proportion of selected nature benefits, we used generalized linear models (GLMs; quasibinomial family for overdispersed data with logit link to meet normality of error distributions). The analysis was only applied for urban parks because green brownfields usually do not contain many gray facilities and sample sizes were too low $(n=13)$ for this type of test. Only the four most frequently mentioned nature benefits were tested (green landscape/ aesthetics, natural elements, regulating ecosystem services, and social and cultural interactions) because other nature benefits such as urban wilderness or sense of place were mentioned in only a few urban parks and sample sizes were too small. Response variables were the proportions of selected nature benefit in all mentioned benefits, respectively, and GLMs were run separating UGS structural dimensions (green, spatial, and gray characteristics). The green model included tree cover, tree and flowering richness as explaining variables. Inhabitant density within $300 \mathrm{~m}$ and size of the site was tested in the spatial model, and number of seating possibilities per hectare, number of lights per hectare, as well as the sum of available sports facilities were tested in the gray model. Because of different measurement units of explaining variables, we calculated standardized coefficients with the "reghelper" package (Hughes 2020). The best model was then selected with the Bayesian Information Criterion (BIC) accounting for small sample sizes $(n=18)$ preferring the least complex model with "BMA" package (Raftery et al. 2020).

\section{RESULTS}

\section{Demographic characteristics of respondents}

We interviewed 1624 park visitors and 255 brownfield users. We excluded respondents who mentioned that they were using the sites as shortcuts, resulting in 1500 and 250 questionnaires of park 
and brownfield users, respectively. Women made up $48 \%$ of the respondents in parks and $42 \%$ on brownfields. Only four respondents specified diverse gender. The majority of the respondents in both UGS types were either young adults $(34 \%$ in parks, $37 \%$ on brownfields) or adults ( $40 \%$ in parks, $46 \%$ on brownfields). Interviewed visitors of brownfields were significantly younger with lower variance (t-test: $p<0.001$; mean: $36 \mathrm{y}, 1^{\text {st }}$ quartile: $25 \mathrm{y}, 3^{\text {rd }}$ Quartile: $45 \mathrm{y}$ ) than visitors of parks (mean: $39 \mathrm{y}, 1^{\text {st }}$ quartile: $25 \mathrm{y}, 3^{\text {rd }}$ quartile: $55 \mathrm{y}$ ). The median of the distance from home or work to the nearest entrance for parks was $814 \mathrm{~m} \mathrm{(} 1^{\text {st }}$ quartile: $321 \mathrm{~m}, 3^{\text {rd }}$ quartile: $\left.1881 \mathrm{~m}\right)$ and $448 \mathrm{~m}$ for brownfields ( $1^{\text {st }}$ quartile: $295 \mathrm{~m}, 3^{\text {rd }}$ quartile: $953 \mathrm{~m}$ ). Of the 1500 park respondents, 886 mentioned one or several benefits and 813 persons mentioned disturbances/disservices. On brownfields, 150 people responded to benefits and 137 persons mentioned disturbances/disservices.

\section{Perception of benefits across age groups}

\section{Urban parks}

Figure 3 shows all green and gray benefits that were perceived by respondents in urban parks. The chi-square test reveals significant differences between age groups $(p<0.001)$. Older persons $(65+$ y) mentioned green landscape/aesthetics as well as urban wilderness aspects including near-natural maintenance more frequently than the other age groups (highest positive Pearson's residuals; Appendix 1, Table A1.2). Natural elements such as trees, flowering aspects, or water elements were other important green benefits for older persons. Along the same lines, older park visitors specified walking $(40 \%$ of senior respondents) and enjoying the landscape $(16 \%)$ as their most frequently used ecosystem service (Appendix 1, Fig. A1.7). Adults between 31 and 64 mentioned infrastructure such as playgrounds, benches, and paths more often than other age groups (Appendix A, Table A1.2). However, similar to older persons, they valued natural elements and features regarding park design and maintenance such as safety and cleanliness most frequently. Walking $(29 \%$ of adults) was the main activity of adult respondents followed by dog walking $(21 \%)$. The youngest age group, young adults (19-30 y), valued spatial aspects such as a decent size/availability and location of the park most frequently followed by park design and maintenance aspects. Comparted to other age groups, young adults placed more importance on sports facilities (Appendix 1, Table A1.2). The most frequently used ecosystem service that $15 \%$ of the young adult respondents specified in the surveys were other activities (e.g., doing sports, reading, sunbathing) and walking.

\section{Green brownfields}

Suitability for dogs as a positive green brownfield aspect was mentioned most frequently by older persons and second- and third-most by adults and young adults, respectively (Fig. 4), although dog walking overall was the main activity ( $52 \%$ of the respondents) of all age groups (Appendix 1, Fig. A1.8). It must be noted that brownfields were used by only a few older persons at or above the age of 65 . Adults mostly valued size/availability and location including statements that the site is the only available UGS near their home. Young adults appreciated wilderness aspects including low maintenance of vegetation the most, which was also important to adults. Furthermore, young adults liked brownfields for their social and cultural interactions. For older age groups, this opportunity seemed to decrease in valuation or not be important at all compared to other benefits (Fig. 4). Brownfields were not only used for walking the dog, but for walking $(10 \%)$ and for other activities such as playing table tennis or relaxing (7\%). Sporadically, respondents used brownfields for meeting people, enjoying landscape beauty, or noise regulation (Appendix 1, Fig. A1.8).

Fig. 3. Frequencies of perceived benefits (categorized answers from open question) in urban parks mentioned by visitors of different age groups in Leipzig. Multiple answers were possible. The white numbers display the number of answers for each age group. Nature benefits are written in green.

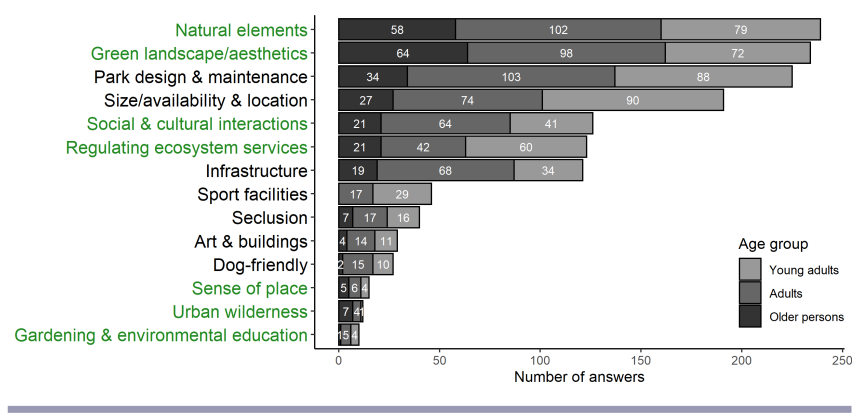

Fig. 4. Frequencies of perceived benefits (categorized answers from open question) on brownfields mentioned by visitors of different age groups on our study sites in Leipzig. Multiple answers were possible. The white numbers display the number of anwers for each age group. Nature benefits are written in green.

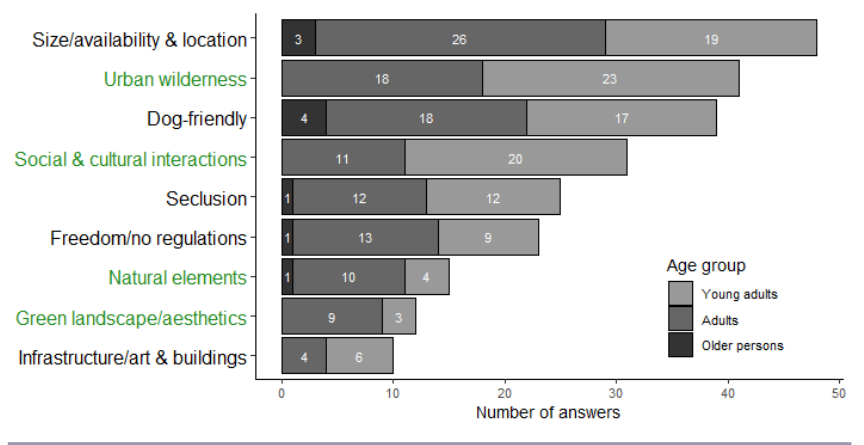

Interactions of benefits and influence of urban green space characteristics

Interactions of benefits

To identify positive (synergies) or negative spatial interactions (trade-offs) between pairs of perceived gray and green benefits in urban parks, we applied a weighted Spearman's correlation test (Fig. 5). In parks, statements about social and cultural interactions show strong positive correlations with perceived infrastructure (0.8) and sports facilities (0.87). We found a slightly negative relationship between social and cultural interactions and regulating ecosystem services, though this correlation is not significant. Regulating ecosystem services show moderate correlation with seclusion (0.51). Answers referring to art and buildings (graffiti, monuments) correlate moderately negative to 
Fig. 5. Correlation matrix (weighted Spearman's correlation) for pairs of perceived benefits in 18 urban parks and 13 urban green brownfields. Numbers below the black diagonal line show correlation coefficients for aspects of urban parks, above the line correlations for urban brownfields. Respondents could name multiple categories. Categories representing nature benefits are in light green; gray benefits are gray. Significant (*on 95\% confidence interval for 1000 bootstrapped resamples, see Appendix 1, Tables A1.4, A1.5) positive or negative correlations $\geq 0.5$ between two nature benefits are marked in light green, correlations between nature benefits and gray benefits are in dark green; correlations between two gray benefits are marked in gray.

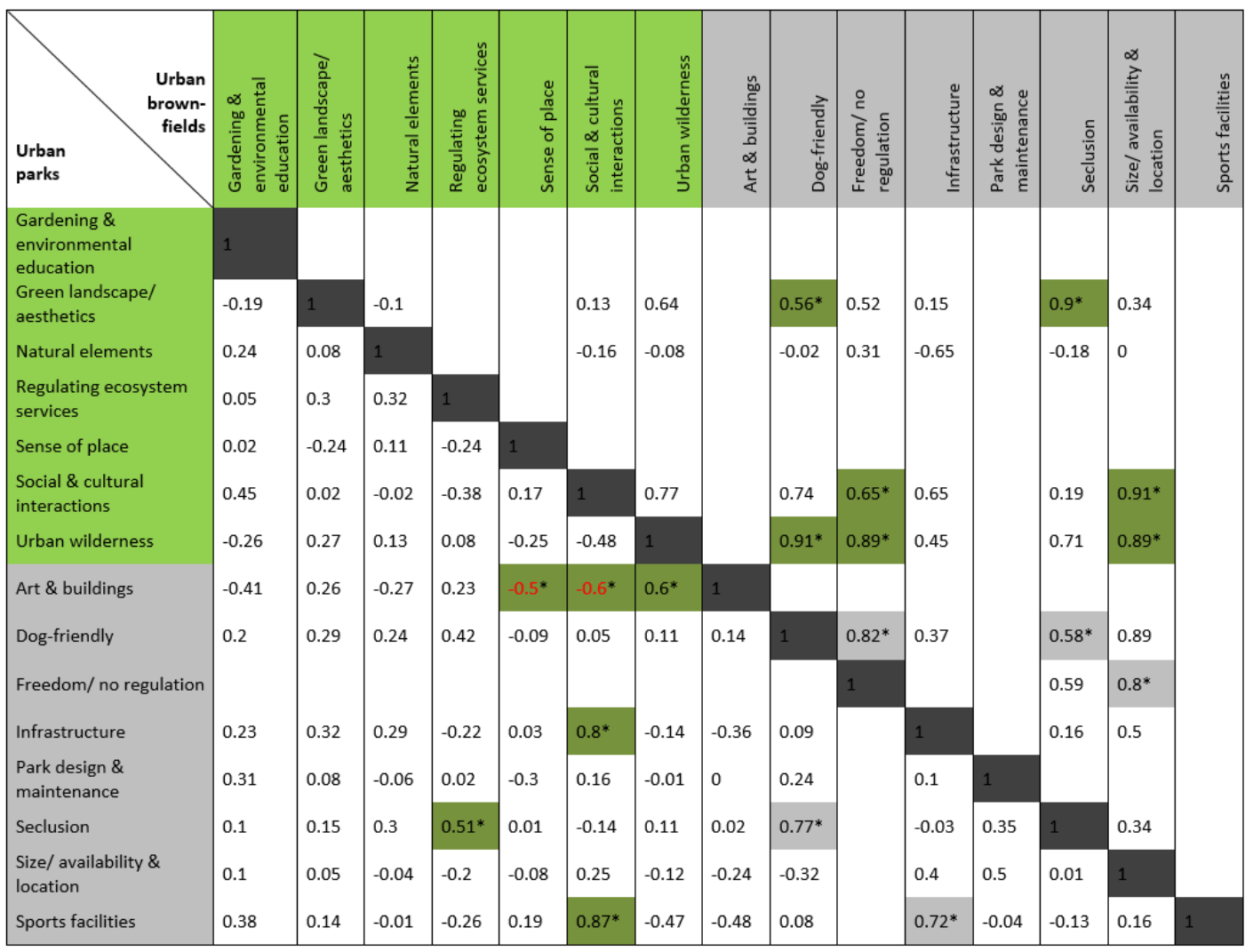

social and cultural interactions (-0.6) and sense of place $(-0.5)$ and positively to urban wilderness $(0.6)$ of parks. Perception of sites being dog friendly correlates positively with seclusion of parks (0.77) as well as brownfields (0.58). The aspects of urban wilderness, dog friendly, freedom/no regulations, size/availability and location, and seclusion mainly positively correlate with each other on brownfields. Enjoying social and cultural interactions as well as urban wilderness on brownfields strongly correlates with people valuing size/availability and location of the site (0.91 and 0.89 ). However, many high positive correlation coefficients of pairs of benefits perceived on brownfields point out that users often mention the same positive aspects and benefits on each of the 13 sites.

\section{Influence of green, spatial, and gray urban green space characteristics on perceived benefits of urban parks}

To test the influence of particular green, spatial, and gray park characteristics on the four most frequently mentioned nature benefits that people perceived in urban parks (natural elements, green landscape/aesthetics, social and cultural interactions, regulating ecosystem services), we performed separated GLMs.
We found no significant predictors for green landscape/aesthetics or nature elements in urban parks (Table 2). The perception of parks providing regulating ecosystem services was significantly positively influenced by tree cover $(p=0.02)$ in the final green model. In the spatial model, inhabitant density within $300 \mathrm{~m}$ showed a slightly negative relationship to this benefit $(p=0.03)$. For social and cultural interactions, tree cover and inhabitant density within $300 \mathrm{~m}$ show an opposite influence compared to regulating ecosystem services. Tree cover relates negatively in the green model $(p=0.03)$ and inhabitant density within $300 \mathrm{~m}$ positively in the spatial model to social and cultural interactions. Inhabitant density within $300 \mathrm{~m}$ shows the strongest positive influence $(p<0.001)$ to social and cultural interactions. There are two significant explaining variables for social and cultural interactions in the final gray model, seating possibilities $(p<0.01)$ as well as sports facilities (e.g., table tennis, basketball courts), whereby sports facilities show a stronger influence $(p<0.001)$. Both predictors have a positive influence on social and cultural interactions. It must be noted that preanalysis revealed collinearity between inhabitant density within $300 \mathrm{~m}$ and sports 
Table 2. Results from separated generalized linear models (quasibinomial family) for green, spatial, and gray urban green space characteristics and four positive categories that represent nature benefits. Only significant coefficients $(*<0.05, * *<0.01, * * *<0.001)$ of the best model (lowest BIC) within each structural dimension after Bayesian Model averaging are shown. The chi-square value specifies the difference in deviance between the model and the null-model, Df indicates degrees of freedom.

\begin{tabular}{|c|c|c|c|c|c|c|c|c|}
\hline \multirow[b]{2}{*}{$\begin{array}{l}\text { Proportion of } \\
\text { nature benefit } \\
\text { among answers }\end{array}$} & \multicolumn{3}{|c|}{ Green model } & \multicolumn{2}{|c|}{ Spatial model } & \multicolumn{3}{|c|}{ Gray model } \\
\hline & $\begin{array}{c}\text { Tree cover of the } \\
\text { site }[\%]\end{array}$ & $\begin{array}{c}\text { Species } \\
\text { richness } \\
\text { trees } \\
{[\text { species/ } 100} \\
\left.\mathrm{m}^{2}\right]\end{array}$ & $\begin{array}{c}\text { Species } \\
\text { richness } \\
\text { flowering } \\
{\left[\begin{array}{c}\text { species/ } 100 \\
\left.\mathrm{~m}^{2}\right]\end{array}\right.}\end{array}$ & $\begin{array}{l}\text { Inhabitant density } \\
\text { within } 300 \mathrm{~m} \text { [No. } \\
\text { of people] }\end{array}$ & $\begin{array}{c}\text { Size of the } \\
\text { site [hectare] }\end{array}$ & $\begin{array}{c}\text { Lights [No./ } \\
\text { hectare] }\end{array}$ & $\begin{array}{c}\text { Seating } \\
\text { possibilities } \\
\text { [No./hectare] }\end{array}$ & $\begin{array}{c}\text { Sports facilities } \\
\text { [No.] }\end{array}$ \\
\hline $\begin{array}{l}\text { Green landscape/ } \\
\text { aesthetics }\end{array}$ & - & - & - & - & - & - & - & - \\
\hline \multirow{2}{*}{$\begin{array}{l}\text { Natural elements } \\
\text { Regulating } \\
\text { ecosystem } \\
\text { services }\end{array}$} & - & - & - & - & - & - & - & - \\
\hline & $\begin{array}{c}0.43 \\
(*)\end{array}$ & & & $\begin{array}{c}-0.41 \\
(*)\end{array}$ & & - & & \\
\hline \multirow{8}{*}{$\begin{array}{l}\text { Social and } \\
\text { cultural } \\
\text { interactions }\end{array}$} & BIC: -41.2 & & & BIC: -42.1 & & & & \\
\hline & $x^{2}: 16.84$ & & & $x^{2}: 15.81$ & & & & \\
\hline & Df: 16 & & & Df: 16 & & & & \\
\hline & -0.5 & & & 0.76 & & & 0.49 & 0.62 \\
\hline & $(*)$ & & & $(* * *)$ & & & $(* *)$ & $(* * *)$ \\
\hline & BIC: -41.2 & & & BIC: -38.1 & & & \multicolumn{2}{|c|}{ BIC: -38.8} \\
\hline & $\chi^{2}: 25.2$ & & & $\chi^{2}: 84.83$ & & & \multicolumn{2}{|c|}{$\chi^{2}: 69.64$} \\
\hline & Df: 16 & & & Df: 16 & & & \multicolumn{2}{|c|}{ Df: 15} \\
\hline
\end{tabular}

facilities (Spearman' rank correlation 0.86) in urban parks. Neither species richness nor size of the site showed significant influence on any of the four nature benefits.

\section{Perception of disturbances/disservices across age groups}

Urban parks

The main disturbance/disservice perceived in all age groups was litter and the lack of waste bins followed by undesired activities of other users (Appendix 1, Fig. A1.9). Although social and cultural interactions such as meeting people were often used (Appendix 1, Fig. A1.7) and appreciated (Fig. 3), especially by adults and young adults, these interactions can be disturbing for others: people barbequing or sitting in groups as well as overcrowded parks were often perceived as negative aspects among respondents (Appendix 1, Fig. A1.10). Older persons especially felt more disturbed by other users compared to other age groups as the chi-square test reveals (Appendix 1, Table A1.3). Also, criminal activities and safety aspects were disturbing for park users. Young adults felt more disturbed by street noise and insufficient shade than other age groups. However, this effect might be caused by one urban park (P11_1, Appendix 1, Table A1.1) that is directly located on a street with no view protection and is predominantly used by young adults.

\section{Green brownfields}

When asked for negative aspects, many respondents called litter being dumped, the lack of waste bins, and insufficient maintenance as the main disturbances/disservices on brownfields (Appendix 1, Fig. A1.11). The positive valuation of urban wilderness aspects including low maintenance activities on the one hand and sites being perceived as neglected on the other hand illustrate the contradictory perception of benefits and disturbances/disservices among respondents (Appendix 1, Fig. A1.12). Other frequently mentioned disturbances/disservices of brownfields were little or no nature mainly referring to the removal of mature trees and the potential loss of the site because of planned conversion, e.g., for housing.

\section{DISCUSSION}

In this study, we aimed to identify age-specific perceptions of benefits as well as disturbances/disservices of two types of UGS and link perceived nature benefits with park characteristics. Respondents were able to address any benefits as well as disturbances/disservices perceived in a UGS they actually visited. This approach enabled us to link visitors' perceptions to specific site characteristics. Older age groups placed more importance on aesthetic benefits and urban wilderness aspects whereas younger age groups valued sports facilities and other infrastructure. The analysis of park characteristics influencing perceived nature benefits announced tree cover, inhabitant density within $300 \mathrm{~m}$ as well as sports facilities and benches as significant predictors for social and cultural interactions or regulating ecosystem services.

\section{Benefits perceived by different age groups}

Results reveal significant differences in derived benefits between age groups and show that older persons enjoy aesthetic benefits and appreciate elements of nature. Middle-aged persons particularly value available infrastructure whereas young adults appreciate sports facilities more than older age groups.

The four most important benefits for park respondents were green landscape/aesthetics, natural elements, park design and maintenance, and size/availability and location. Furthermore, with respect to brownfields, respondents appreciated urban wilderness including near-natural conditions very frequently. These benefits represent four of the six key human dimensions of environmental quality that Gobster and Westphal (2004) identified in an urban greenway in Chicago, USA: aesthetics, 
naturalness, cleanliness, and access. Wilderness aspects and natural elements refer to the naturalness dimension and are very important to older persons (Gibson 2018).

Besides flowering aspects and water bodies, the most frequently mentioned natural element in urban parks were trees. Trees in parks and streets contribute to people's well-being by reducing stress, noise, and air temperature and improve aesthetical values and scenery (Lohr et al. 2003, Roy et al. 2012). Lohr et al. (2003) reported that young people between 18 and 21 placed less importance on trees for their quality of life than older age groups. Similarly, our study revealed that natural elements such as large trees and flowering aspects were mainly appreciated by older persons and less by young adults between 18 and 30. Under consideration of increasing temperatures in the summer, the presence of trees providing shade was especially important for older age groups. Exemplified by another study in Leipzig, older age groups avoid parks with low tree cover when temperatures are too hot underlining the importance of considering age-specific needs and values in UGS planning (Kabisch and Kraemer 2020). Older age groups accordingly enjoyed landscape beauty, a nature benefit that necessarily includes natural elements, more often than young adults. Enjoying nature or landscape beauty, representing the aesthetic dimension, and the possibility of being in contact with nature as important UGS benefits, especially for older age groups, has also been highlighted by other studies (Chiesura 2004, Matsuoka and Kaplan 2008, Shan 2014).

Young adults, on the other hand, placed more importance on design and maintenance aspects of urban parks, e.g., separate locations for different activities, safety aspects, or large open lawns as well as decent park size or proximity to their home (size/ availability and location), referring to the cleanliness and access dimension. These results suggest that nearby UGS designed for activities like doing sports, reading, or meeting people is especially important for young adults because these were their most frequently performed activities. Studies in other European cities (Gothenburg and Amsterdam), in Santa Cruz in Bolivia, and a national survey in Germany found similar results for park visitors of different age groups, in which younger people were more engaged in sporting and meeting others, whereas older age groups were more frequently walking, watching, and enjoying nature favoring a more natural design of UGS (Wright Wendel et al. 2012, Gartenamtsleiterkonferenz 2014, Ode Sang et al. 2016, Gibson 2018, Knight et al. 2018). In accordance with these studies, our findings confirm these cross-cultural age specific preferences for ecosystem service types and benefits derived from UGS.

\section{Influence of green, spatial, and gray characteristics on perceived benefits}

Our analysis reveals the positive influence of high tree cover to regulating services such as noise mediation or shade provision, whereas social and cultural interactions were more appreciated in urban parks with low tree cover, especially with high inhabitant density within $300 \mathrm{~m}$. Available infrastructure (benches, sports facilities) further facilitated social and cultural interactions. Contrary to our expectations, we found no significant association between either species richness or actual size of the UGS and perceived nature benefits.

Plenty of respondents found parks in densely populated residential areas suitable for children, meeting other families, or for other social and cultural interactions. These parks serve as places for everyday social life, which can contribute to reducing the feeling of loneliness and thereby improving psychological health (Van Herzele and Wiedemann 2003, Maas et al. 2009, Wright Wendel et al. 2012). This benefit seems to be less important in parks located in neighborhoods with low residential density. Additionally in those parks, positively influenced by high tree cover, residents appreciated regulating services more frequently. Social and cultural interactions and regulating services even show a slightly oppositional relationship underlining different functional levels of parks referring to their location of either inside or outside densely populated areas (Van Herzele and Wiedemann 2003). Public parks with high tree cover outside residential areas can fulfill nature-related activities such as enjoying fresh air and quietness whereas accessible residential or neighborhood UGS predominantly support social relations (Maas et al. 2009, Shan 2014). Park visitors in Leipzig liked neighborhood parks, i.e., parks in densely populated neighborhoods, for their "different cultures, from young to old" and described them as a "meeting point for different cultures."

Results from this study further illustrate a positive association between facilities for sitting or for doing sports and social and cultural interactions. It must be noted, however, that we counted more sports infrastructure in parks with high inhabitant density in the neighborhood. It thus cannot be clearly determined if inhabitant density or sports facilities finally influenced social and cultural interactions. Other studies point out the importance of high-quality facilities for active (doing sports, physical activity) or resting (sitting) recreational activities in public parks (Gearin and Kahle 2006, Kaczynski et al. 2008, McCormack et al. 2010). Complementing these findings, infrastructure for active and resting recreation can additionally stimulate social and cultural interactions. The presence of soccer fields, for example, connects children and teenagers of different ages and cultures and the availability of open lawns can create a busy atmosphere for active recreation or socializing (Peters et al. 2010, Ignatieva et al. 2017, Ćwik et al. 2018).

On the issue of open lawns, our results also show a positive association between low tree cover and social and cultural interactions. Some respondents exemplified this by describing the sites as places where "they see and are being seen by other people." Interestingly, a study in Baltimore, USA, found tree cover in the neighborhood positively influencing social capital (Holtan et al. 2014). In their study, Holtan et al. (2014) referred to total tree cover on the neighborhood level instead of the park level as showing a positive influence of tree cover on social bonds and social interactions. Our study complements these findings by revealing a reverse relationship between tree canopy and perceived social benefits when it is examined at the UGS level. Because most urban parks in Leipzig fall within the medium or high tree cover class and natural tree growth will lead to increasing tree cover over the years, these findings underscore the importance of including open areas and lawns in parks in densely populated neighborhoods.

\section{Disturbances/disservices and conflicts}

Besides benefits, there are some age group specific disturbances/ disservices, such as feeling disturbed by activities of other people, which was especially true for older persons 65 years and above. 
They disliked other visitors' behavior or activities such as groups of people being noisy or leaving litter and causing smoke from barbequing, as well as the overuse of UGS (overcrowded parks). These conflicts must be considered in design and maintenance of UGS. The implementation of separate areas for different activities such as barbeque areas including sufficient waste bins, especially in intensively used neighborhood parks, for instance, can contribute to reducing these conflicts. However, separate areas that are less visible and under less surveillance by other park users might foster criminal activities, groups of people consuming drugs and alcohol, or vandalism. Safety and crime were among the main concerns of UGS users, and perceived safety risks can lead to decreased use (Koskela and Pain 2000, Adinolfi et al. 2014). Urban green space design should therefore support usability by not only including appropriate infrastructure and spatial configuration but also by maintaining it on a regular basis and by providing sufficient lighting. However, the negative impacts of increased lights on the night sky and the absence of natural darkness for biodiversity (Longcore and Rich 2004, Pauwels et al. 2019) but also human health (Lyytimäki and Rinne 2013) must be considered in UGS planning. By applying measures to reduce disturbances and conflicts, UGS can then function as places to strengthen social cohesion with neighbors instead of creating disservices (Peters et al. 2010).

Another frequently mentioned problem was the presence of unleashed dogs and their feces in public parks. Only a few parks in Leipzig provide designated dog areas and facilities, and when provided, they are usually not fenced in such that dogs may escape the designated area. Based on our study, urban brownfields contribute to decreasing this conflict (see also Palliwoda et al. 2020). Although far from being visited as frequently as urban parks, green brownfields are mainly used by dog walkers confirming findings from other studies in Leipzig (Rall and Haase 2011, Pueffel et al. 2018). Brownfield visitors appreciated the availability of the open spaces, which are often more secluded than urban parks and hence provide suitable spaces for dogs. The average brownfield user mainly lived close by and these sites were often the only available UGS near their homes. We thus argue to view highly frequented brownfields not only as important for dog owners, but for a broader audience and to integrate these informal sites into the city-wide UGS network to reduce use and user conflicts in public parks and to increase the availability of UGS close to people's homes.

Often connected to dog suitability, the "wild" or near-natural character was one of the main positive aspects of brownfields that users appreciated, underlining the chances of informal and lessmanaged types of UGS for providing nature experiences and adding more nature to the city (Chiesura 2004, Rall and Haase 2011). However, confirmed by our and previous studies, littering was one of the main disturbances/disservices on brownfields and some people found them rather unattractive clearly preferring well-maintained public parks (Rall and Haase 2011, Bixler and Floyd 1997, Farahani and Maller 2019). Nevertheless, at the same time, cities can be hotspots for nature conservation, nature experiences, and biodiversity, especially when they contain spontaneous and less-manicured vegetation (Dunn et al. 2006, O'Farrell et al. 2012, Breuste et al. 2013). We thus call for diverse UGS including "wild areas" with regular waste removal that can fulfill diverse users' preferences, contribute to urban biodiversity, and simultaneously reduce trade-offs between ecosystem services and recreational use in public green spaces.

\section{Limitations of the study}

Although people were visiting a specific UGS, we let them describe in their own words any positive (benefit) and negative aspects (disturbance/disservice) of this UGS. With this qualitative approach, we aimed to avoid biases in actual personal perceptions by predefining any benefits or disturbances/disservices. However, open ended questions may not cover all benefits that respondents derive from UGS because people may not be aware of intangible benefits such as microclimate regulation or intellectual values.

The linkage with green UGS characteristics, especially with species richness, implies further limitations. Species assessments were conducted on randomly distributed plots in 2017 that may not be representative for 2018 or cover total species richness of the study site. During the questioning, perceptions of respondents may be influenced by their direct environment (observation unit) in which surveys were conducted, and they may not refer to the park or brownfield as a whole. Hence, people's perceptions and present UGS characteristics that were tested in the GLMs may not always refer to the same spatial unit.

Some urban parks or brownfields are specifically used by certain age groups and therefore aspects of that site may be overrepresented in survey results among these age groups. For instance, if a park with lots of sports infrastructure is primarily used by young adults then this might be reflected in high frequencies of the benefit "sports facilities" among this age group. However, we argue that effects of present characteristics and perceived benefits can still be captured by surveying actual users of certain UGS, whom we assume choose this specific UGS according to their personal preferences.

\section{CONCLUSION}

The growing number of inhabitants in Leipzig can be expected to increase demand for and use of the city's UGS. In this study, we highlighted important UGS characteristics that can encourage the perception of nature benefits and other aspects by UGS users. Some positive aspects and benefits support multifunctional UGS use whereas others show antagonistic relationships, requiring careful and purposeful planning and management. Public parks with medium to high tree cover encourage the use of regulating services such as noise reduction and shade provision, which are directly experienced by people. Trees providing sufficient shade are therefore important green elements of UGS, especially for older age groups that are more vulnerable to increasing temperatures in the summer. As Leipzig is driven by population growth mainly caused by young adults who move into densely populated areas, it is considered important to understand their preferences and UGS uses as well as potential conflicts among uses and users. Well maintained and equipped neighborhood parks are needed and valued especially by younger users and facilitate social ties and social relations in residential areas.

Urban green space users' contrasting perceptions and valuations of features and other users' activities increase the challenge for UGS planning and management, especially in Leipzig's context of growing demands. High appreciation of urban wilderness on brownfields as informal UGS suggests that many urban residents support nature-oriented and reduced UGS management, 
decreasing not only costs, but increasing nature experiences and fostering urban biodiversity. To create UGS providing a broad range of benefits and ecosystem services for all demographic user groups, the integration of diverse UGS including alternative management concepts into the city-wide network of urban green can help to decrease perceived disturbances and conflicts contributing to sustainable urban development.

Responses to this article can be read online at: https://www.ecologyandsociety.org/issues/responses. php/12204

\section{Acknowledgments:}

The study is part of the UrbanGaia project (http://urbangaia.eul), which is funded by BiodivErsA, project number 01LC1616A. We thank the city of Leipzig's Office of Green Space and Freshwater for input and support with study site selection and all participants of the surveys. We would like to thank Nina Schwarz for contributing to the study during the initial phase of the project. Thanks to Mina Krieger for supporting the field work, Leslie and Ben Jakobs for helping with data digitalization. and Mick Wu for statistical advice. Further data digitalization and assessments were performed by Zdenka Smutna, Sandra Wilken, and Samuel Karrer, and we are thankful for their support. Last but not least, we thank the two anonymous reviewers and editor for their valuable comments.

\section{Data Availability:}

Datalcode openly available in a public repository that issues datasets with DOIs The datalcode that support the findings of this study are openly available in Open Sciene framework at https:/losf.io/rfnpy/ DOI 10.17605/OSF.IO/RFNPY,

\section{LITERATURE CITED}

Adinolfi, C., G. P. Suárez-Cáceres, and P. Cariñanos. 2014. Relation between visitors' behaviour and characteristics of green spaces in the city of Granada, south-eastern Spain. Urban Forestry and Urban Greening 13(3):534-542. https://doi. org/10.1016/j.ufug.2014.03.007

Arbeitskreis Deutscher Markt (ADM). 2021. Richtlinie für die Befragung von Minderjährigen. ADM, Berlin, Germany. [online] URL: https://www.adm-ev.de/wp-content/uploads/2021/01/RLMinderjaehrigen-neu-2021.pdf

Banzhaf, E., T. Arndt, and J. Ladiges. 2018. Potentials of urban brownfields for improving the quality of urban space. Pages 221-232 in S. Kabisch, F. Koch, E. Gawel, A. Haase, S. Knapp, K. Krellenberg, J. Nivala, and A. Zehnsdorf, editors. Urban transformations. Sustainable urban development through resource effciency, quality of life and resilience. Springer, Berlin, Germany. https://doi.org/10.1007/978-3-319-59324-1_12

Banzhaf, E., H. Kollai, and A. Kindler. 2020. Mapping urban gray and green structures for liveable cities using a 3D enhanced OBIA approach and vital statistics. Geocarta International 35:623-640. https://doi.org/10.1080/10106049.2018.1524514
Barbosa, O., J. A. Tratalos, P. R. Armsworth, R. G. Davies, R. A. Fuller, P. Johnson, and K. J. Gaston. 2007. Who benefits from access to green space? A case study from Sheffield, UK. Landscape and Urban Planning 83(2-3):187-195. https://doi.org/10.1016/j. landurbplan.2007.04.004

Battisti, L., L. Pille, T. Wachtel, F. Larcher, and I. Säumel. 2019. Residential greenery: state of the art and health-related ecosystem services and disservices in the City of Berlin. Sustainability 11 (6):1815. https://doi.org/10.3390/su11061815

Bertram, C., and K. Rehdanz. 2015. Preferences for cultural urban ecosystem services: comparing attitudes, perception, and use. Ecosystem Services 12:187-199. https://doi.org/10.1016/j. ecoser.2014.12.011

Bijker, R. A., and F. J. Sijtsma. 2017. A portfolio of natural places: using a participatory GIS tool to compare the appreciation and use of green spaces inside and outside urban areas by urban residents. Landscape and Urban Planning 158:155-165. https://doi. org/10.1016/j.landurbplan.2016.10.004

Bird, W. 2004. Can green space and biodiversity increase levels of physical activity? Royal Society for the Protection of Birds, Bedfordshire, UK.

Bixler, R. D., and M. F. Floyd. 1997. Nature is scary, disgusting, and uncomfortable. Environment and Behavior 29(4):443-467. https://doi.org/10.1177/001391659702900401

Bjerke, T., T. Østdahl, C. Thrane, and E. Strumse. 2006. Vegetation density of urban parks and perceived appropriateness for recreation. Urban Forestry and Urban Greening 5(1):35-44. https://doi.org/10.1016/j.ufug.2006.01.006

Bolund, P., and S. Hunhammar. 1999. Ecosystem services in urban areas. Ecological Economics 29:293-301. https://doi. org/10.1016/S0921-8009(99)00013-0

Breuste, J., J. Schnellinger, S. Qureshi, and A. Faggi. 2013. Urban ecosystem services on the local level: urban green spaces as providers. Ekologia 32(3):290-304. [online] URL: https://content. sciendo.com/downloadpdf/journals/eko/32/3/article-p290.xml

Bundesregierung. 2016. Deutsche Nachhaltigkeitsstrategie. Frankfurt am Main. Bundesregierung, Berlin, Germany. [online] URL: https://www.bundesregierung.de/breg-de/themen/ nachhaltigkeitspolitik/eine-strategie-begleitet-uns/die-deutschenachhaltigkeitsstrategie

Chiesura, A. 2004. The role of urban parks for the sustainable city. Landscape and Urban Planning 68(1):129-138. https://doi. org/10.1016/j.landurbplan.2003.08.003

Ćwik, A., I. Kasprzyk, T. Wójcik, K. Borycka, and P. Cariñanos. 2018. Attractiveness of urban parks for visitors versus their potential allergenic hazard: a case study in Rzeszów, Poland. Urban Forestry and Urban Greening 35:221-229. https://doi. org/10.1016/j.ufug.2018.09.009

Dallimer, M., K. N. Irvine, A. M. J. Skinner, Z. G. Davies, J. R. Rouquette, L. L. Maltby, P. H. Warren, P. R. Armsworth, and K. J. Gaston. 2012. Biodiversity and the feel-good factor: understanding associations between self-reported human wellbeing and species richness. BioScience 62(1):47-55. https://doi. org/10.1525/bio.2012.62.1.9 
D'Amato, G. D. 2000. Urban air pollution and plant-derived respiratory allergy. Clinical and Experimental Allergy 30:628-636. https://doi.org/10.1046/j.1365-2222.2000.00798.x

de Vries, S., R. A. Verheij, P. P. Groenewegen, and P. Spreeuwenberg. 2003. Natural environments - healthy environments? An exploratory analysis of the relationship between greenspace and health. Environment and Planning 35:1717-1731. https://doi.org/10.1068/a35111

Díaz, S., S. Demissew, J. Carabias, C. Joly, M. Lonsdale, N. Ash, A. Larigauderie, J. R. Adhikari, S. Arico, A. Báldi, A. Bartuska, I. A. Baste, A. Bilgin, E. Brondizio, K. M. A. Chan, V. E. Figueroa, A. Duraiappah, M. Fischer, R. Hill, T. Koetz, P. Leadley, P. Lyver, G. M. Mace, B. Martin-Lopez, M. Okumura, D. Pacheco, U. Pascual, E. S. Pérez, B. Reyers, E. Roth, O. Saito, R. J. Scholes, N. Sharma, H. Tallis, R. Thaman, R. Watson, T. Yahara, Z. A. Hamid, C. Akosim, Y. Al-Hafedh, R. Allahverdiyev, E. Amankwah, S. T. Asah, Z. Asfaw, G. Bartus, L. A. Brooks, J. Caillaux, G. Dalle, D. Darnaedi, A. Driver, G. Erpul, P. EscobarEyzaguirre, P. Failler, A. M. M. Fouda, B. Fu, H. Gundimeda, S. Hashimoto, F. Homer, S. Lavorel, G. Lichtenstein, W. A. Mala, W. Mandivenyi, P. Matczak, C. Mbizvo, M. Mehrdadi, J. P. Metzger, J. B. Mikissa, H. Moller, H. A. Mooney, P. Mumby, H. Nagendra, C. Nesshover, A. A. Oteng-Yeboah, G. Pataki, M. Roué, J. Rubis, M. Schultz, P. Smith, R. Sumaila, K. Takeuchi, S. Thomas, M. Verma, Y. Yeo-Chang, and D. Zlatanova. 2015. The IPBES conceptual framework - connecting nature and people. Current Opinion in Environmental Sustainability 14:1-16. https:// doi.org/10.1016/j.cosust.2014.11.002

Dunn, R. R., M. C. Gavin, M. C. Sanchez, and J. N. Solomon. 2006. The pigeon paradox: dependence of global conservation on urban nature. Conservation Biology 20(6):1814-1816. https://doi. org/10.1111/j.1523-1739.2006.00533.x

Eigenbrod, C., and N. Gruda. 2015. Urban vegetable for food security in cities. A review. Agronomy for Sustainable Development 35(2):483-498. https://doi.org/10.1007/s13593-014-0273-y

Elmqvist, T., H. Setälä, S. N. Handel, S. van der Ploeg, J. Aronson, J. N. Blignaut, E. Gómez-Baggethun, D. J. Nowak, J. Kronenberg, and R. de Groot. 2015. Benefits of restoring ecosystem services in urban areas. Current Opinion in Environmental Sustainability 14:101-108. https://doi.org/10.1016/j.cosust.2015.05.001

Farahani, L. M., and C. Maller. 2019. Investigating the benefits of 'leftover' places: residents' use and perceptions of an informal greenspace in Melbourne. Urban Forestry and Urban Greening 41:292-302. https://doi.org/10.1016/j.ufug.2019.04.017

Fuller, R. A., K. N. Irvine, P. Devine-Wright, P. H. Warren, and K. J. Gaston. 2007. Psychological benefits of greenspace increase with biodiversity. Biology Letters 3(4):390-394. https://doi. org/10.1098/rsbl.2007.0149

Gartenamtsleiterkonferenz (GALK). 2014. Wie zufrieden sind Bürger mit städtischen Grünflächen? Ergebnisse der vierten bundesweiten Internetbefragung. GALK, Hamburg, Germany. [online] URL: galk.de/component/jdownloads/send/34internetbefragung/273-ergebnisse-2014?option=com jdownloads

Gearin, E., and C. Kahle. 2006. Teen and adult perceptions of urban green space Los Angeles. Children, Youth and Environments
16:25-48. [online] URL: http://www.actrees.org/files/ Research/16_1_02_TeenPerceptions.pdf

Gibson, S. C. 2018. "Let's go to the park." An investigation of older adults in Australia and their motivations for park visitation. Landscape and Urban Planning 180:234-246. https://doi. org/10.1016/j.landurbplan.2018.08.019

Giles-Corti, B., M. H. Broomhall, M. Knuiman, C. Collins, K. Douglas, K. Ng, A. Lange, and R. J. Donovan. 2005. Increasing walking: how important is distance to, attractiveness, and size of public open space? American Journal of Preventative Medicine 28 (2 Suppl 2):169-176.

Gobster, P. H., and L. M. Westphal. 2004. The human dimensions of urban greenways: planning for recreation and related experiences. Landscape and Urban Planning 68(2-3):147-165. https://doi.org/10.1016/S0169-2046(03)00162-2

Gómez-Baggethun, E., and D. N. Barton. 2013. Classifying and valuing ecosystem services for urban planning. Ecological Economics 86:235-245. https://doi.org/10.1016/j.ecolecon.2012.08.019

Haase, D. 2008. Urban ecology of shrinking cities: an unrecognized opportunity? Nature and Culture 3(1):1-8.

Haase, D., N. Schwarz, M. Strohbach, F. Kroll, and R. Seppelt. 2012. Synergies, trade-offs, and losses of ecosystem services in urban regions: an integrated multiscale framework applied to the Leipzig-Halle Region, Germany. Ecology and Society 17(3):22. https://doi.org/10.5751/ES-04853-170322

Haines-Young, R., and M. Potschin. 2013. Common international classification of ecosystem services (CICES): consultation on version 4, August-December 2012. EEA Framework Contract No EEA/IEA/09/003 European Environment Agency, Copenhagen, Denmark. [online] URL: https://cices.eu/ content/uploads/sites/8/2012/07/CICES-V43 Revised-

Final_Report 29012013.pdf

Hami, A., and F. Emami. 2015. Spatial quality of natural elements and safety perception in urban parks. International conference on agricultural, ecological and medical sciences (AEMS-2015) Feb. 10-11, 2015 Penang (Malaysia). IICBE. [online] URL: https:// iicbe.org/upload/7928C0215153.pdf

Hegetschweiler, K. T., S. de Vries, A. Arnberger, S. Bell, M. Brennan, N. Siter, A. S. Olafsson, A. Voigt, and M. Hunziker. 2017. Linking demand and supply factors in identifying cultural ecosystem services of urban green infrastructures: a review of European studies. Urban Forestry and Urban Greening 21:48-59. https://doi.org/10.1016/j.ufug.2016.11.002

Hermy, M., and J. Cornelis. 2000. Towards a monitoring method and a number of multifaceted and hierarchical biodiversity indicators for urban and suburban parks. Landscape and Urban Planning 49(3-4):149-162. https://doi.org/10.1016/S0169-2046 (00)00061-X

Hofmann, M., J. R. Westermann, I. Kowarik, and E. van der Meer. 2012. Perceptions of parks and urban derelict land by landscape planners and residents. Urban Forestry and Urban Greening 11(3):303-312. https://doi.org/10.1016/j.ufug.2012.04.001

Holtan, M. T., S. L. Dieterlen, and W. C. Sullivan. 2014. Social life under cover: tree canopy and social capital in Baltimore, 
Maryland. Environment and Behavior 47(5):502-525. https://doi. org/10.1177/0013916513518064

Hughes, J. 2020. reghelper: helper functions for regression analysis. $\mathrm{R}$ package version 1.0.0. The $\mathrm{R}$ Foundation for Statistical Computing, Vienna, Austria. https://CRAN.R-project.org/ package $=$ reghelper

Ignatieva, M., F. Eriksson, T. Eriksson, P. Berg, and M. Hedblom. 2017. The lawn as a social and cultural phenomenon in Sweden. Urban Forestry and Urban Greening 21:213-223. https://doi. org/10.1016/j.ufug.2016.12.006

Jim, C. Y., and W. Y. Chen. 2006. Perception and attitude of residents toward urban green spaces in Guangzhou (China). Environmental Management 38(3):338-349. https://doi.org/10.1007/ $\underline{\mathrm{s} 00267-005-0166-6}$

Jorgensen, A., and A. Anthopoulou. 2007. Enjoyment and fear in urban woodlands - does age make a difference? Urban Forestry and Urban Greening 6(4):267-278. https://doi.org/10.1016/j. ufug.2007.05.004

Kabisch, N., and R. Kraemer. 2020. Physical activity patterns in two differently characterised urban parks under conditions of summer heat. Environmental Science and Policy 107:56-65. https:// doi.org/10.1016/j.envsci.2020.02.008

Kaczynski, A. T., and K. A. Henderson. 2008. Parks and recreation settings and active living: a review of associations with physical activity function and intensity. Journal of Physical Activity and Health 5:619-632. https://doi.org/10.1123/jpah.5.4.619

Kaczynski, A. T., L. R. Potwarka, and B. E. Saelens. 2008. Association of park size, distance, and features with physical activity in neighborhood parks. American Journal of Public Health 98(8):1451-1456. https://doi.org/10.2105/AJPH.2007.129064

Kessel, A., J. Green, R. Pinder, P. Wilkinson, C. Grundy, and K. Lachowycz. 2009. Multidisciplinary research in public health: a case study of research on access to green space. Public Health 123 (1):32-38. https://doi.org/10.1016/j.puhe.2008.08.005

Kienast, F., B. Degenhardt, B. Weilenmann, Y. Wäger, and M. Buchecker. 2012. GIS-assisted mapping of landscape suitability for nearby recreation. Landscape and Urban Planning 105 (4):385-399. https://doi.org/10.1016/j.landurbplan.2012.01.015

Knight, A., R. Black, R. Whitsed, and R. Harvey. 2018. Enhancing the usability and benefits of open space for older people in regional Australia. Australian Planner 55(2):73-83. https://doi.org/10.1080/07293682.2018.1521454

Koskela, H., and R. Pain. 2000. Revisiting fear and place: women's fear of attack and the built environment. Geoforum 31:269-280. https://doi.org/10.1016/S0016-7185(99)00033-0

Kowarik, I. 2005. Wild urban woodlands: towards a conceptual framework. Pages 1-32 in I. Kowarik and S. Körner, editors. Wild urban woodlands. New perspectives for urban forestry. Springer, Berlin, Germany. https://doi.org/10.1007/3-540-26859-6_1

Kowarik, I. 2013. Cities and wilderness. A new perspective. International Journal of Wilderness 19(32-36).
Krellenberg, K., J. Welz, and S. Reyes-Päcke. 2014. Urban green areas and their potential for social interaction - a case study of a socio-economically mixed neighbourhood in Santiago de Chile. Habitat International 44:11-21. https://doi.org/10.1016/j. $\underline{\text { habitatint.2014.04.004 }}$

Kremer, P., Z. Hamstead, D. Haase, T. McPhearson, N. Frantzeskaki, E. Andersson, N. Kabisch, N. Larondelle, E. L. Rall, A. Voigt, F. Baró, C. Bertram, E. Gómez-Baggethun, R. Hansen, A. Kaczorowska, J.-H. Kain, J. Kronenberg, J. Langemeyer, S. Pauleit, K. Rehdanz, M. Schewenius, C. van Ham, D. Wurster, and T. Elmqvist. 2016. Key insights for the future of urban ecosystem services research. Ecology and Society 21(2):29. https://doi.org/10.5751/ES-08445-210229

Langemeyer, J., and J. J. T. Connolly. 2020. Weaving notions of justice into urban ecosystem services research and practice. Environmental Science and Policy 109:1-14. https://doi. org/10.1016/j.envsci.2020.03.021

Lee, A. C., and R. Maheswaran. 2011. The health benefits of urban green spaces: a review of the evidence. Journal of Public Health 33(2):212-222. https://doi.org/10.1093/pubmed/fdq068

Liu, J., Y. Xiong, Y. Wang, and T. Luo. 2018. Soundscape effects on visiting experience in city park: a case study in Fuzhou, China. Urban Forestry and Urban Greening 31:38-47. https://doi. org/10.1016/j.ufug.2018.01.022

Lodenius, M. 2004. Shores in the city: opportunities, threats and challenges - viewpoints of citizens in Helsinki. Boreal Environmental Research 9:491-498.

Lohr, V. I., C. H. Pearson-Mims, J. Tarnai, and D. A. Dillman. 2003. How urban residents rate and rand the benefits and problems associated with trees in cities. Journal of Arboriculture 30(1):28-35.

Longcore, T., and C. Rich. 2004. Ecological light pollution. Frontiers in Ecology and the Environment 2(4):191-198. https://doi. org/10.1890/1540-9295(2004)002[0191:ELP]2.0.CO;2

Lyytimäki, J., L. K. Petersen, B. Normander, and P. Bezák. 2008. Nature as a nuisance? Ecosystem services and disservices to urban lifestyle. Environmental Sciences 5(3):161-172. https://doi. org/10.1080/15693430802055524

Lyytimäki, J., and J. Rinne. 2013. Voices for the darkness: online survey on public perceptions on light pollution as an environmental problem. Journal of Integrative Environmental Sciences 10(2):127-139. https://doi.org/10.1080/1943815X.2013.824487

Maas, J., S. M. E. van Dillen, R. A. Verheij, and P. P. Groenewegen. 2009. Social contacts as a possible mechanism behind the relation between green space and health. Health Place 15(2):586-595. https://doi.org/10.1016/j.healthplace.2008.09.006

Mathey, J., T. Arndt, J. Banse, and D. Rink. 2016. Public perception of spontaneous vegetation on brownfields in urban areas - results from surveys in Dresden and Leipzig (Germany). Urban Forestry and Urban Greening 29:384-392. https://doi. org/10.1016/j.ufug.2016.10.007 
Mathey, J., and D. Rink. 2020. Greening brownfields in urban redevelopment. Pages 1-15 in R. A. Meyers, editor. Encyclopedia of sustainability science and technology Springer, Berlin, Germany.

Mathey, J., S. Rößler, J. Banse, I. Lehmann, and A. Bräuer. 2015. Brownfields as an element of green infrastructure for implementing ecosystem services into urban areas. Urban Planning and Development 141(3). https://doi.org/10.1061/(ASCE) $\underline{\text { UP.1943-5444.0000275 }}$

Matsuoka, R. H., and R. Kaplan. 2008. People needs in the urban landscape: analysis of landscape and urban planning contributions. Landscape and Urban Planning 84(1):7-19. https:// doi.org/10.1016/j.landurbplan.2007.09.009

McCormack, G. R., M. Rock, A. M. Toohey, and D. Hignell. 2010. Characteristics of urban parks associated with park use and physical activity: a review of qualitative research. Health and Place 16(4):712-726. https://doi.org/10.1016/j.healthplace.2010.03.003

Millennium Ecosystem Assessment (MEA). 2005. Ecosystems and human well-being: synthesis. Island, Washington, D.C., USA. [online] URL: https://www.millenniumassessment.org/documents/ document.356.aspx.pdf>

Muratet, A., N. Machon, F. Jiguet, J. Moret, and E. Porcher. 2007. The role of urban structures in the distribution of wasteland flora in the greater Paris Area, France. Ecosystems 10(4):661-671. https://doi.org/10.1007/s10021-007-9047-6

Nordh, H., C. Alalouch, and T. Hartig. 2011. Assessing restorative components of small urban parks using conjoint methodology. Urban Forestry and Urban Greening 10(2):95-103. https://doi.org/10.1016/j.ufug.2010.12.003

O'Farrell, P. J., P. M. L. Anderson, D. C. Le Maitre, and P. M. Holmes. 2012. Insights and opportunities offered by a rapid ecosystem service assessment in promoting a conservation agenda in an urban biodiversity hotspot. Ecology and Society 17(3):27. http://dx.doi.org/10.5751/ES-04886-170327

Ode Sang, Å., I. Knez, B. Gunnarsson, and M. Hedblom. 2016. The effects of naturalness, gender, and age on how urban green space is perceived and used. Urban Forestry and Urban Greening 18:268-276. https://doi.org/10.1016/j.ufug.2016.06.008

Palliwoda, J., E. Banzhaf, and J. A. Priess. 2020. How do the green components of urban green infrastructure influence the use of ecosystem services? Examples from Leipzig, Germany. Landscape Ecology 35:1127-1142. https://doi.org/10.1007/s10980-020-01004$\underline{\mathrm{W}}$

Palliwoda, J., I. Kowarik, and M. von der Lippe. 2017. Humanbiodiversity interactions in urban parks: the species level matters. Landscape and Urban Planning 157:394-406. https://doi. org/10.1016/j.landurbplan.2016.09.003

Pauwels, J., I. Le Viol, C. Azam, N. Valet, J.-F. Julien, Y. Bas, C. Lemarchand, A. S. de Miguel, and C. Kerbirioua. 2019. Accounting for artificial light impact on bat activity for a biodiversity-friendly urban planning. Landscape and Urban Planning 183:12-25. https://doi.org/10.1016/j.landurbplan.2018.08.030

Peschardt, K. K., and U. K. Stigsdotter. 2013. Associations between park characteristics and perceived restorativeness of small public urban green spaces. Landscape and Urban Planning 112:26-39. https://doi.org/10.1016/j.landurbplan.2012.12.013

Peters, K., B. Elands, and A. Buijs. 2010. Social interactions in urban parks: stimulating social cohesion? Urban Forestry and Urban Greening 9(2):93-100. https://doi.org/10.1016/j.ufug.2009.11.003

Plieninger, T., S. Dijks, E. Oteros-Rozas, and C. Bieling. 2013. Assessing, mapping, and quantifying cultural ecosystem services at community level. Land Use Policy 33:118-129. https://doi. org/10.1016/j.landusepol.2012.12.013

Pueffel, C., D. Haase, and J. A. Priess. 2018. Mapping ecosystem services on brownfields in Leipzig, Germany. Ecosystem Services 30:73-85. https://doi.org/10.1016/j.ecoser.2018.01.011

R Core Team. 2020. R: a language and environment for statistical computing. R Foundation for Statistical Computing, Vienna, Austria. [online] URL: https://www.R-project.org/

Raftery, A., J. Hoeting, C. Volinsky, I. Painter, and K. Y. Yeung. 2020. BMA: Bayesian model averaging. $\mathrm{R}$ package version 3.18.12. $\mathrm{R}$ Foundation for Statistical Computing, Vienna, Austria. [online] URL: https://CRAN.R-project.org/package= $\underline{\text { BMA }}$

Rall, E. L., and D. Haase. 2011. Creative intervention in a dynamic city: a sustainability assessment of an interim use strategy for brownfields in Leipzig, Germany. Landscape and Urban Planning 100(3):189-201. https://doi.org/10.1016/j.landurbplan.2010.12.004

Ries, A. V., J. Gittelsohn, C. C. Voorhee, K. M. Roche, K. J. Clifton, and N. M. Astone. 2008. The environment and urban adolescents' use of recreational facilities for physical activity: a qualitative study. American Journal of Health Promotion 23 (1):43-50. https://doi.org/10.4278/ajhp.07043042

Roy, S., J. Byrne, and C. Pickering. 2012. A systematic quantitative review of urban tree benefits, costs, and assessment methods across cities in different climatic zones. Urban Forestry and Urban Greening 11(4):351-363. https://doi.org/10.1016/j.ufug.2012.06.006

Russo, A., F. J. Escobedo, G. T. Cirella, and S. Zerbe. 2017. Edible green infrastructure: an approach and review of provisioning ecosystem services and disservices in urban environments. Agriculture, Ecosystems and Environment 242:53-66. https://doi. org/10.1016/j.agee.2017.03.026

Schetke, S., S. Qureshi, S. Lautenbach, and N. Kabisch. 2016. What determines the use of urban green spaces in highly urbanized areas? Examples from two fast growing Asian cities. Urban Forestry and Urban Greening 16:150-159. https://doi. org/10.1016/j.ufug.2016.02.009

Schipperijn, J., P. Bentsen, J. Troelsen, M. Toftager, and U. K. Stigsdotter. 2013. Associations between physical activity and characteristics of urban green space. Urban Forestry and Urban Greening 12(1):109-116. https://doi.org/10.1016/j.ufug.2012.12.002

Shan, X.-Z. 2014. Socio-demographic variation in motives for visiting urban green spaces in a large Chinese city. Habitat International 41:114-120. https://doi.org/10.1016/j.habitatint.2013.07.012 
Stadt Leipzig. 2017c. Brachflächenkataster Leipzig (Cadastre of brownfields, Leipzig). Amt für Stadtgrün und Gewässer, Leipzig, Germany.

Stadt Leipzig. 2017b. Entwurf Integriertes Stadtentwicklungskonzept "Leipzig 2030" (INSEK). Der Oberbürgermeister Dezernat Stadtentwicklung und Bau, Stadt Leipzig, Germany. [online] URL: https://static.leipzig.de/fileadmin/mediendatenbank/leipzigde/Stadt/02.6 Dez6 Stadtentwicklung Bau/61 Stadtplanungsamt/ Stadtentwicklung/Stadtentwicklungskonzept/INSEK/GesamtdokumentINSEK red.pdf

Stadt Leipzig. 2017a. Freiraumstrategie der Stadt Leipzig. Dezernat Umwelt, Ordnung, Sport, Amt für Stadtgrün und Gewässer, Stadt Leipzig, Germnay. [online] URL: https://static. leipzig.de/fileadmin/mediendatenbank/leipzig-de/

Stadt/02.3_Dez3_Umwelt_Ordnung_Sport/67_Amt_fuer_Stadtgruen_und_Gewaesser/Freiraumstrategie/Freiraumstrategie_Textfassung. pdf

Stadt Leipzig. 2018. Einwohnerdaten Leipzig. (Population data Leipzig). Ordnungsamt/Melderegister, Leipzig, Germnay.

Stadt Leipzig. 2019. Ortsteilkatalog 2018: Strukturdaten der Ortsteile und Stadtbezirke. (Municipal Statistics 2018, in German). Amt für Statistik und Wahlen, Leipzig, Germany. [online] URL: https://static.leipzig.de/fileadmin/mediendatenbank/ leipzig-de/Stadt/02.1_Dez1_Allgemeine Verwaltung/12 Statistik und Wahlen/Raumbezug/Ortsteilkatalog/Ortsteilkatalog 2018. pdf

Stadt Leipzig. 2020. Facts and figures 2020. Amt für Statistik und Wahlen, Stadt Leipzig, Germany. [online] URL: https://static. leipzig.de/fileadmin/mediendatenbank/leipzig-de/

$\underline{\text { Stadt/02.1 Dez1 Allgemeine Verwaltung/12 Statistik und Wahlen/ }}$ Statistik/Leipzig fb Facts and Figures.pdf

Timperio, A., B. Giles-Corti, D. Crawford, N. Andrianopoulos, K. Ball, J. Salmon, and C. Hume. 2008. Features of public open spaces and physical activity among children: findings from the CLAN Study. Preventive Medicine 47:514-518. https://doi. org/10.1016/j.ypmed.2008.07.015

Toftager, M., O. Ekholm, J. Schipperijn, U. Stigsdotter, P. Bentsen, M. Grønæk, T. B. Randrup, and F. Kamper-Jørgensen. 2011. Distance to green space and physical activity: a Danish national representative survey. Journal of Physical Activity and Health 8:741-749. https://doi.org/10.1123/jpah.8.6.741

Tzoulas, K., and P. James. 2010. Peoples' use of, and concerns about, green space networks: a case study of Birchwood, Warrington New Town, UK. Urban Forestry and Urban Greening 9(2):121-128. https://doi.org/10.1016/j.ufug.2009.12.001

Tzoulas, K., K. Korpela, S. Venn, V. Yli-Pelkonen, A. Kaźmierczak, J. Niemela, and P. James. 2007. Promoting ecosystem and human health in urban areas using green infrastructure: a literature review. Landscape and Urban Planning 81(3):167-178. https://doi.org/10.1016/j.landurbplan.2007.02.001

United Nations. 2017. New urban agenda. United Nations, Quito, Ecuador. [online] URL: https://habitat3.org/wp-content/uploads/ NUA-English.pdf
Van Herzele, A., and T. Wiedemann. 2003. A monitoring tool for the provision of accessible and attractive urban green spaces. Landscape and Urban Planning 63(2):109-126. https://doi. org/10.1016/S0169-2046(02)00192-5

Voigt, A., N. Kabisch, D. Wurster, D. Haase, and J. Breuste. 2014. Structural diversity: a multi-dimensional approach to assess recreational services in urban parks. Ambio 43(4):480-491. https:// doi.org/10.1007/s13280-014-0508-9

Wickham, H. 2016. ggplot2: elegant graphics for data analysis. Springer, New York, New York, USA.

Wright Wendel, H. E., R. K. Zarger, and J. R. Mihelcic. 2012. Accessibility and usability: green space preferences, perceptions, and barriers in a rapidly urbanizing city in Latin America. Landscape and Urban Planning 107(3):272-282. https://doi. org/10.1016/j.landurbplan.2012.06.003 
Appendix 1 
Table A1.1: Green, spatial, and grey characteristics of study sites, mean age of respondents and number of conducted valid suryes.

\begin{tabular}{|c|c|c|c|c|c|c|c|c|c|c|c|c|}
\hline Site ID & Type & Place name & $\begin{array}{l}\text { Share of } \\
\text { tree } \\
\text { cover }\end{array}$ & $\begin{array}{l}\text { Tree } \\
\text { richness } \\
\text { per } \\
\text { 100m2 }\end{array}$ & $\begin{array}{l}\text { Flowering } \\
\text { richness } \\
\text { per } 100 \mathrm{~m} 2\end{array}$ & $\begin{array}{l}\text { Size of } \\
\text { the site } \\
\text { (ha) }\end{array}$ & $\begin{array}{l}\text { Inhabitant } \\
\mathrm{s} \text { in 300m }\end{array}$ & $\begin{array}{l}\text { Seating } \\
\text { possibilities } \\
\text { per hectare }\end{array}$ & $\begin{array}{l}\text { Lighting } \\
\text { per } \\
\text { hectare }\end{array}$ & $\begin{array}{l}\text { Sport } \\
\text { facilities } \\
\text { (sum) }\end{array}$ & $\begin{array}{l}\text { Mean age of } \\
\text { respondents }\end{array}$ & $\begin{array}{l}\text { Number } \\
\text { of } \\
\text { surveys }\end{array}$ \\
\hline B01_1 & Brownfield & Saalfelder Str. & 21.04 & 0.22 & 4 & 1.21 & 3437.27 & 0 & 0 & 0 & 39 & 30 \\
\hline B08_1 & Brownfield & Torgauer Platz & 8.74 & 0.22 & 2.89 & 2.38 & 4076.59 & 0 & 3.36 & 0 & 38.31 & 15 \\
\hline B08_2 & Brownfield & Kirschbergerstr. & 38.67 & 2.37 & 0.59 & 5.1 & 2970.81 & 0 & 0.78 & 0 & 48.83 & 38 \\
\hline B10_1 & Brownfield & Bayerischer Bahnhof & 6.67 & 0.44 & 1.96 & 8.81 & 7238.92 & 0 & 0.57 & 0 & 34.97 & 38 \\
\hline B11_1 & Brownfield & Kochstr. & 14.82 & 0.32 & 32 & 0.06 & 3271.96 & 47.32 & 0 & 0 & 42.83 & 6 \\
\hline B12_2 & Brownfield & Friedrich-Ebert-Str. & 53.73 & 0.27 & 14 & 0.4 & 3811.47 & 2.49 & 0 & 0 & 30 & 6 \\
\hline B16_3 & Brownfield & Zweinaundorfer Str. & 97.66 & 0.89 & 0.22 & 1.67 & 4573.94 & 0 & 0 & 0 & 32.2 & 10 \\
\hline B17_2 & Brownfield & Saarlaender Str. & 36.02 & 0.15 & 12 & 0.39 & 250.46 & 0 & 5.12 & 0 & 25 & 1 \\
\hline B17_3 & Brownfield & Luetzener Str./Odermannstr. & 96.13 & 0.92 & 8 & 0.1 & 4488.31 & 0 & 0 & 0 & 32.56 & 10 \\
\hline B18_1 & Brownfield & Zschochersche/ Makranstaedter Str. & 7.54 & 0 & 2.67 & 1.33 & 1691.87 & 0 & 0 & 0 & 29.73 & 11 \\
\hline B18_2 & Brownfield & Delitzscher Str. & 37.57 & 0.67 & 4 & 0.13 & 3416.31 & 0 & 0 & 0 & NA & 0 \\
\hline B19_3 & Brownfield & Bernhardiplatz & 77.86 & 0.41 & 0 & 0.29 & 5161.78 & 0 & 0 & 0 & NA & 0 \\
\hline B20_3 & Brownfield & Ossietzkystr. & 70 & 1.02 & 0 & 0.09 & 3269.88 & 0 & 0 & 0 & NA & 0 \\
\hline B21_2 & Brownfield & Eisenbahnstr. & 54.64 & 0.54 & 10 & 0.17 & 6626.56 & 30.22 & 0 & 1 & 27 & 19 \\
\hline B21_3 & Brownfield & Friedhof Mockau & 82.13 & 1.56 & 0 & 1.37 & 2322.08 & 0 & 0 & 0 & NA & 0 \\
\hline B22_1 & Brownfield & Jahrtausendfeld & 2.2 & 0.67 & 3.56 & 2.65 & 4839.66 & 1.51 & 0 & 1 & 31.57 & 64 \\
\hline B22_3 & Brownfield & Max-Liebermann Str. & 75 & 2.44 & 0 & 0.72 & 609.96 & 0 & 0 & 0 & NA & 0 \\
\hline B24_2 & Brownfield & Bernhardstrasse & 64.94 & 0.77 & 10 & 0.12 & 4669.03 & 0 & 0 & 0 & 30 & 2 \\
\hline P01_2 & Park & Arthur-Bretschneider Park & 58.44 & 1.11 & 0.67 & 3.05 & 4156.66 & 8.2 & 0 & 0 & 43.69 & 111 \\
\hline P02_3 & Park & Heinrich Schuetz Platz & 76.85 & 0.44 & 0 & 1.45 & 8442.99 & 5.51 & 5.51 & 3 & 39.49 & 80 \\
\hline P03_3 & Park & Gustav Schwabe Platz & 89.59 & 2 & 0 & 1.19 & 3549.24 & 15.94 & 6.71 & 1 & 49.49 & 51 \\
\hline P04_1 & Park & Rabet & 18.4 & 0.59 & 0.44 & 6.28 & 11526.01 & 8.29 & 8.29 & 8 & 37.34 & 117 \\
\hline P04_2 & Park & Lenné Anlage & 65.76 & 0.67 & 0.44 & 1.38 & 1744.17 & 7.27 & 2.91 & 0 & 34.29 & 71 \\
\hline P04_3 & Park & Richard Wagner Platz & 79.19 & 0.89 & 0.89 & 1.02 & 3436.43 & 5.9 & 7.86 & 0 & 44.46 & 97 \\
\hline P05_1 & Park & Henriettenpark & 9.72 & 0.67 & 1.56 & 1.18 & 5987.78 & 12.68 & 18.6 & 2 & 33.18 & 88 \\
\hline P05_2 & Park & Goethestrasse/ Schwanenteich & 53.82 & 1.56 & 0 & 2.55 & 1653.5 & 6.28 & 3.53 & 0 & 43.74 & 102 \\
\hline
\end{tabular}




\begin{tabular}{|c|c|c|c|c|c|c|c|c|c|c|c|c|}
\hline P08_1 & Park & Rosental & 13.84 & 0.05 & 0.44 & 21.32 & 3166.65 & 3.05 & 0 & 0 & 43.75 & 103 \\
\hline P08_2 & Park & Palmengarten & 55.54 & 0.53 & 0.81 & 20.96 & 4329.02 & 3.34 & 1.1 & 0 & 39.72 & 78 \\
\hline P08_3 & Park & Wilhelm Kuelz Park & 68.55 & 0.44 & 0 & 18.52 & 1282.33 & 2.65 & 1.03 & 0 & 42.73 & 26 \\
\hline P09_2 & Park & Friedenspark & 61.62 & 0.5 & 0.33 & 18.02 & 6044.99 & 1.66 & 0.06 & 7 & 38.9 & 81 \\
\hline P09_3 & Park & Emmauskirchplatz & 84.11 & 0.67 & 0.22 & 0.73 & 2798.3 & 8.22 & 4.11 & 0 & 45.85 & 60 \\
\hline P10_2 & Park & Mariannenpark & 62.28 & 0.74 & 0.15 & 16.78 & 5355.2 & 5.96 & 0 & 2 & 36.61 & 87 \\
\hline P11_1 & Park & Alexis Schumann Platz & 23.09 & 1.11 & 2.89 & 0.72 & 6761.4 & 16.63 & 6.93 & 1 & 29.35 & 86 \\
\hline P11_3 & Park & Reudnitzer Park & 72.8 & 1.78 & 0 & 2.1 & 6454.46 & 9.53 & 3.81 & 2 & 35.75 & 80 \\
\hline P13_1 & Park & Lene Voigt Park & 19.91 & 0.67 & 0.11 & 9.26 & 12214.46 & 7.34 & 6.8 & 7 & 32.16 & 111 \\
\hline P14_1 & Park & Abtnaundorfer Park & 32 & 1.33 & 2.11 & 8.85 & 1137.51 & 2.15 & 0 & 0 & 45.52 & 71 \\
\hline
\end{tabular}






\section{Figure A1.1}

Two examples of urban parks with low tree cover (P13_1; P04_1) (Photos: J. Palliwoda)

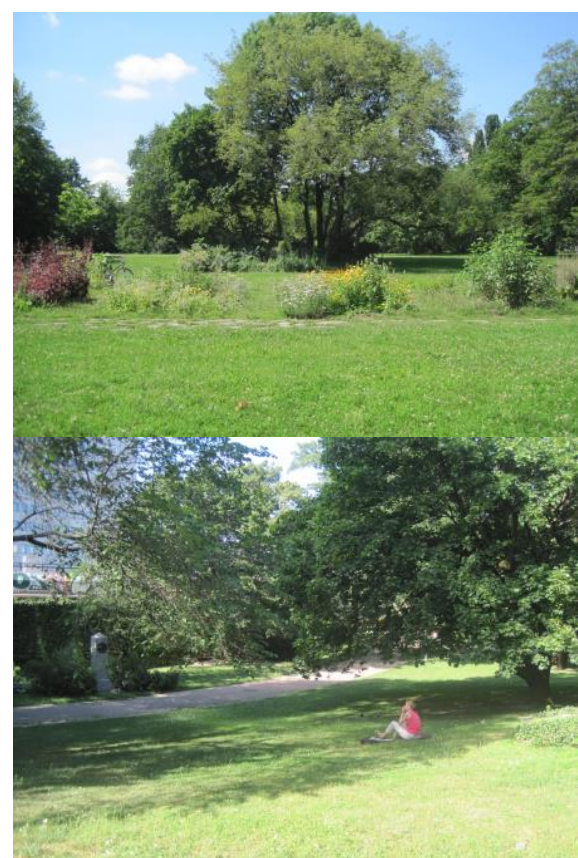

\section{Figure A1.2}

Two examples of urban parks with medium tree cover (P08_2, P04_2) (Photos: J. Palliwoda)

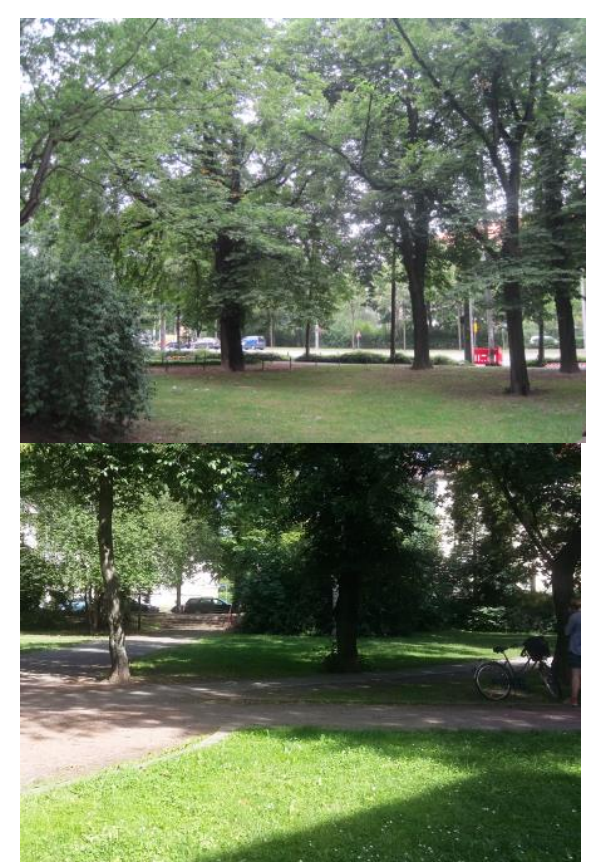

\section{Figure A1.3}

Two examples of urban parks with high tree cover (P04_3, P09_3) (Photos: J. Palliwoda) 


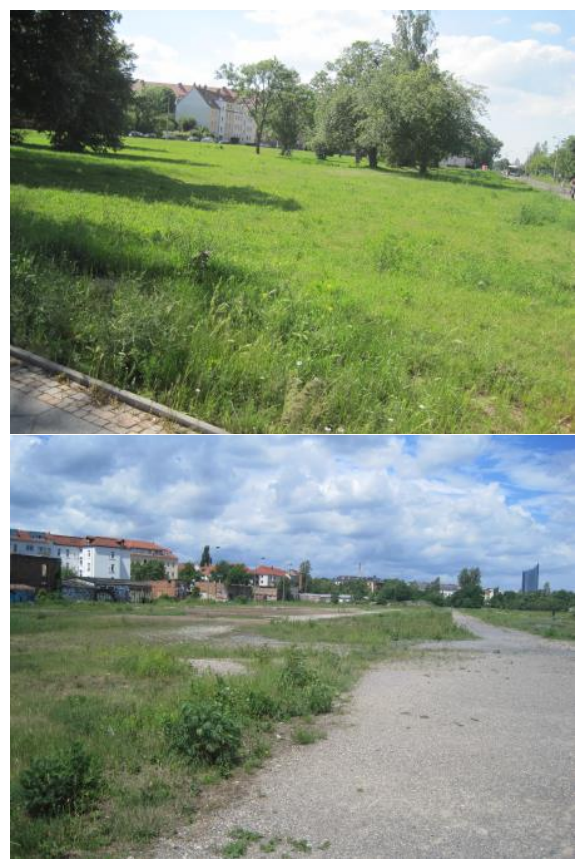

\section{Figure A1.4}

Two examples of green brownfields with low tree cover (B01_1; B10_1) (Photos: J. Palliwoda)

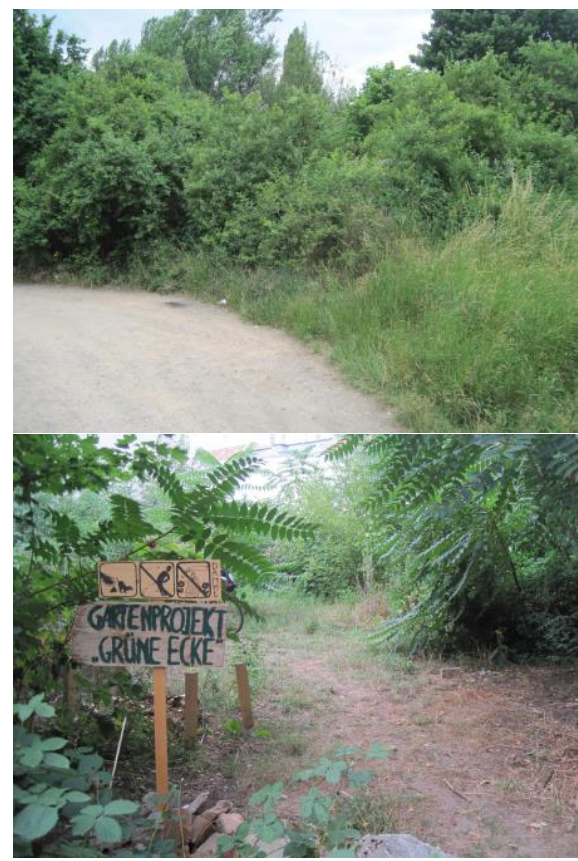

\section{Figure A1.5}

Two examples of green brownfields with medium tree cover (B08_2, B24_2) (Photos: J. Palliwoda)

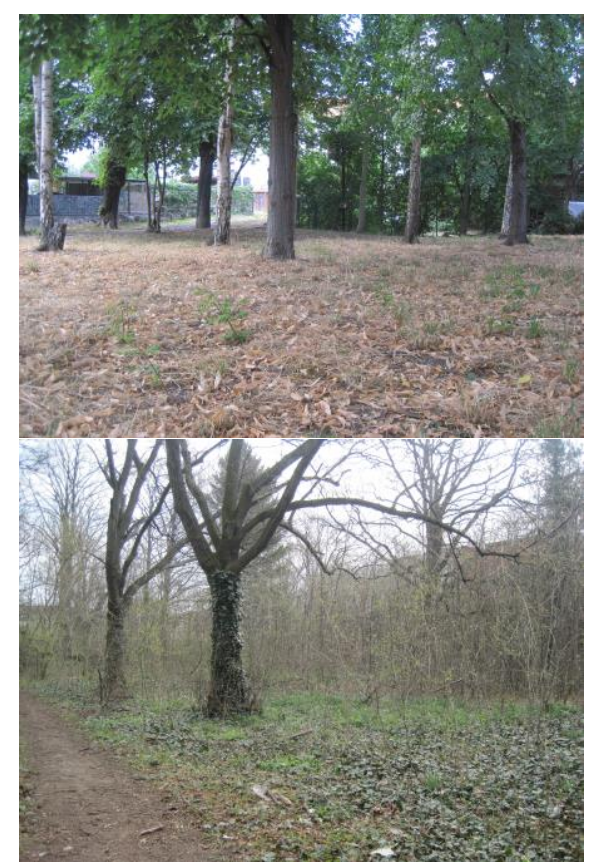

\section{Figure A1.6}

Two examples of green brownfields with high tree cover (B17_3, B21_3) (Photos: J. Palliwoda) 


\section{Survey about the use of nature in parks and brownfields}

... Your introduction text

\section{Question 1}

What do you use/enjoy/ disturbs you here? (Please choose one activity only)

[ ] Collecting food from plants

[ ] Drinking water

[ ] Collecting medicine, fibres etc. from plants or animals

[ ] Using energy from plants

[ ] Draft animal or mount

[ ] Providing shade and shelter

[ ] Mediating smell, noise, visual impacts

[ ] Experience diversity of plants \& animals

[ ] Watching animals or plants

[ ] Enjoy landscape beauty

[ ] Experience cultural heritage, sense of place

[ ] Doing research, (environmental) education

[ ] Sacred or religious plants or animals

[ ] Being inspired by nature
[ ] Sport fishing or hunting

[ ] Biking

[ ] Walking the dog

[ ] Walking, strolling, hiking

[ ] Jogging, running

[ ] Meeting people

[ ] Barbequeing, picnicing

[ ] Camping

[ ] Gardening

[ ] Doing other activities in nature:

[ ] Unsightly landscape (Due to natural reasons)

[ ] Causes hayfever/ allergic reaction

[ ] Pests (mosquitos, flies)

[ ] Bad water quality

[ ] Threatening site

[ ] Other problems (e.g. animal excrements; intruding animals or plants)

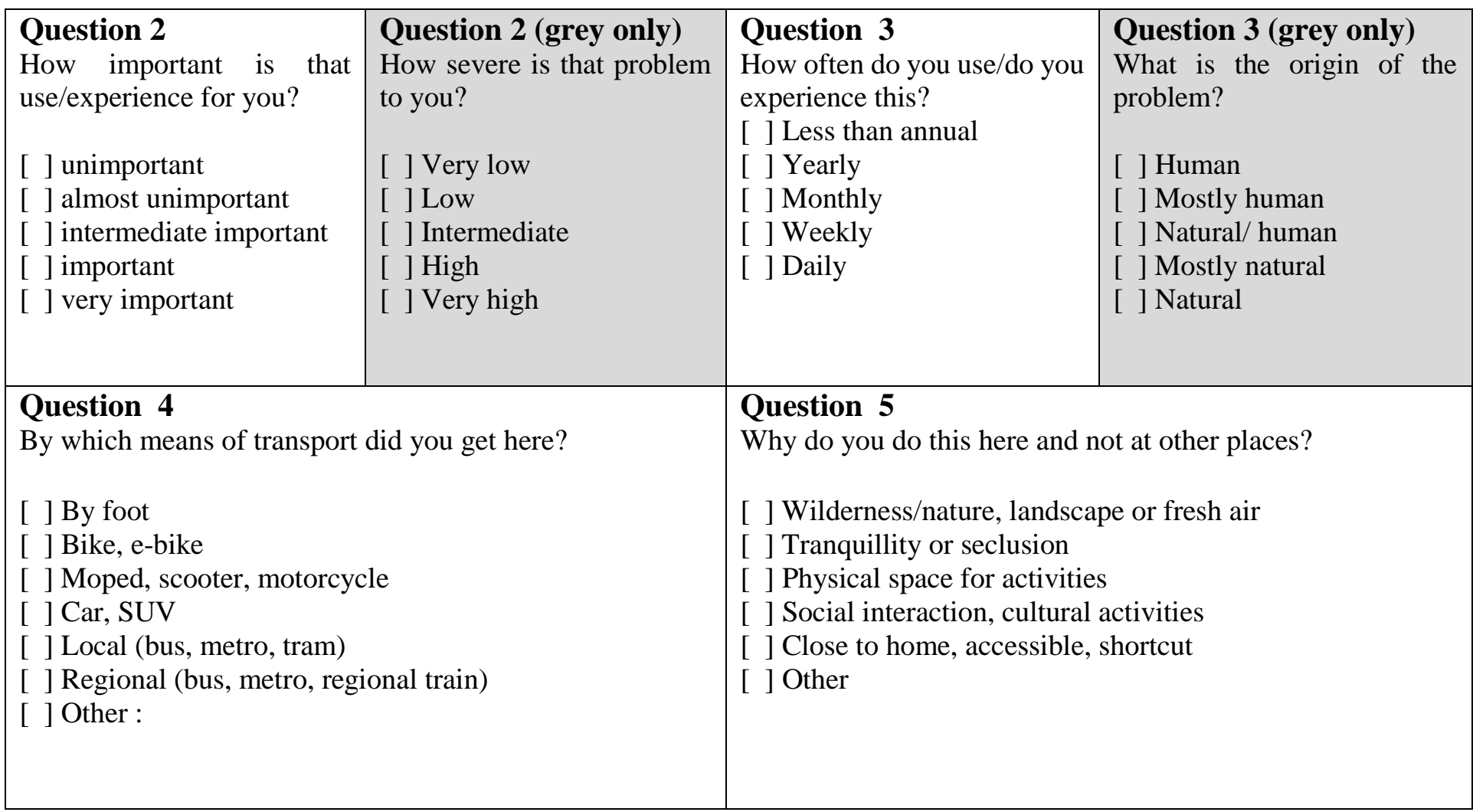


If you want, you can leave a comment:

1) What do you like about the site? 2) What do you dislike or feel disturbed by?

Personal data:

City:

Street:

Postcode:

Gender: [ ] female [ ] male [ ] diverse

Age:___ OR Age group: [ ] -19 [ ] 20-29 [ ] 30-39 [ ] 40-49 [ ] 50-59 [ ] 60-69 [ ] 70+

Thank you for participating at the survey!

Internal information:

\begin{tabular}{|l|l|}
\hline Date/ day of the week: & \\
\hline Time: & \\
\hline Site ID: & \\
\hline Interviewer: & \\
\hline Weather conditions: & \\
\hline Shade/sun: & \\
\hline $\begin{array}{l}\text { Location(Path, } \\
\text { meadow, ...): }\end{array}$ & \\
\hline Moving/Resting: & \\
\hline Other: & \\
\hline
\end{tabular}


Table A1.2: Pearson's residuals of chi-square test for benefits in urban parks. Positive values mean a positive association between age group and benefit, negative values mean negative association between age group and benefit $(\mathrm{p}<0.001)$. Highest positive residuals are marked in grey.

\begin{tabular}{|l|l|l|l|}
\hline Benefit & Young adults (18-30y) & Adults (31-64y) & Older persons (65+y) \\
\hline Art \& buildings & 0.04 & 0.37 & -0.62 \\
\hline Dog-friendly & -0.04 & 0.93 & -1.36 \\
\hline Gardening \& environmental education & 0.13 & 0.3 & -0.64 \\
\hline Green landscape/aesthetics & -1.68 & -0.43 & 3.03 \\
\hline Infrastructure & -1.69 & 2.07 & -0.78 \\
\hline Natural elements & -1.12 & -0.25 & 1.96 \\
\hline Park design \& maintenance & 0.4 & 0.46 & -1.27 \\
\hline Regulating ecosystem services & 2.05 & -1.61 & -0.44 \\
\hline Seclusion & 0.26 & -0.12 & -0.19 \\
\hline Sense of place & -0.68 & -0.22 & 1.3 \\
\hline Size/availability \& location & 2.18 & -1.04 & -1.48 \\
\hline Social \& cultural interactions & -0.91 & 1.2 & -0.55 \\
\hline Sport facilities & 2.83 & -0.7 & -2.94 \\
\hline Wilderness & -1.65 & -0.55 & 3.16 \\
\hline
\end{tabular}

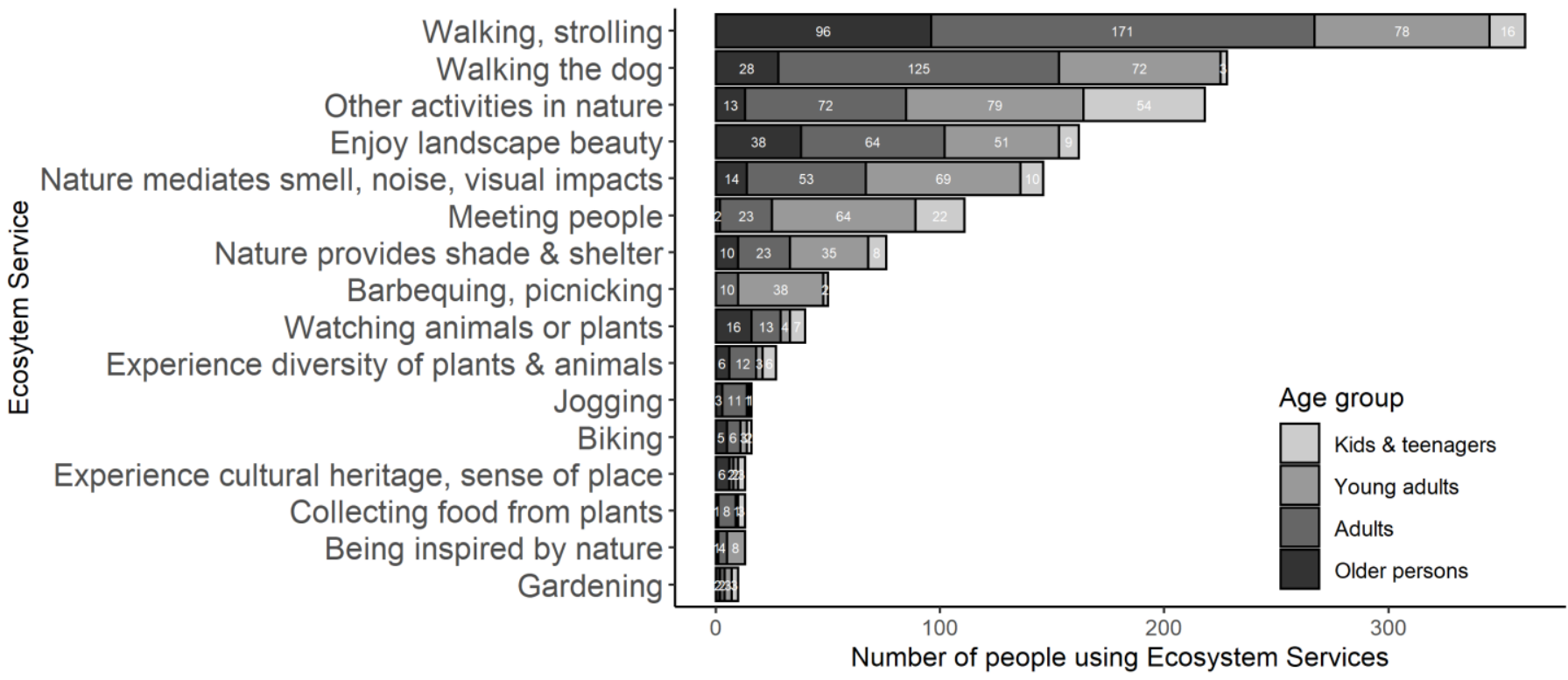

Figure A1.7: Respondents of different age groups from surveys $(n=1500)$ in urban parks and their used ecosystem service (question with predefined ecosystem services). Ecosystem services that were used from less than 10 respondents were aggregated in "Other activities in nature" for graphical reasons. 




Figure A1.8: Respondents of different age groups from surveys $(n=250)$ on brownfields and their ecosystem used service (question with predefined ecosystem services). Ecosystem services that were used from less than 10 respondents were aggregated in "Other activities in nature" for graphical reasons.



Figure A1.9: Frequencies of perceived disturbances/disservices (categorized answer from open question) in urban parks mentioned by respondents of different age groups in Leipzig. Multiple answers were possible. The white numbers display the number of answers for each age group. 


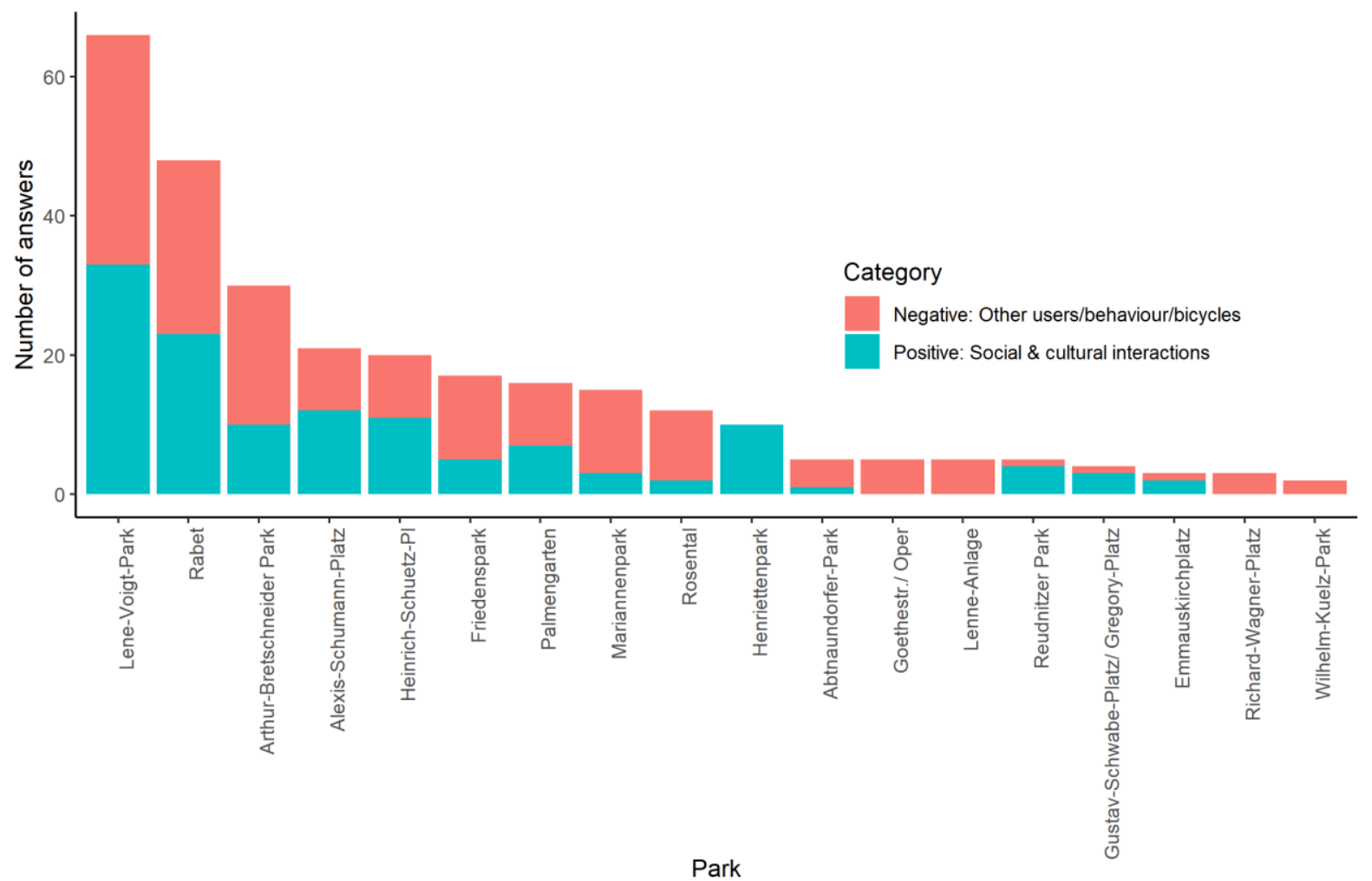

Figure A1.10: Trade-offs between social \& cultural interactions as perceived benefits (positive) and people feeling disturbed (negative) by other users and their activities in 18 urban parks (categorized answers from open question).

Table A1.3: Pearson's residuals of chi-square test for perceived disturbances in urban parks. Positive values mean a positive association between age group and disturbance, negative values mean negative association between age group and disturbance $(p<0.001)$. Highest positive residuals are marked in grey.

\begin{tabular}{|l|l|l|l|}
\hline Disturbance & Young adults (18-30y) & Adults (31-64y) & Older persons (65+y) \\
\hline Dogs & -1.59 & 1.18 & 0.37 \\
\hline Little/no nature & 2.13 & -1.14 & -1.22 \\
\hline Missing/bad infrastructure & -0.49 & 0.27 & 0.27 \\
\hline Noise/little shade & 3.64 & -1.92 & -2.12 \\
\hline Other users/behaviour/bicycles & -1.84 & 0.35 & 2.11 \\
\hline Saftey/crime & -0.81 & 0.84 & -0.21 \\
\hline Litter/waste & -0.01 & 0.33 & -0.54 \\
\hline Unsuitable design \& maintenance & 1.5 & -1.41 & 0.15 \\
\hline Vandalism & -1.67 & 0.95 & 0.85 \\
\hline
\end{tabular}






Figure A1.11: Frequencies of perceived disturbances/disservices (categorized answer from open question) on brownfields mentioned by respondents of different age groups in Leipzig. Multiple answers were possible. The white numbers indicate the number of mentions for each age group

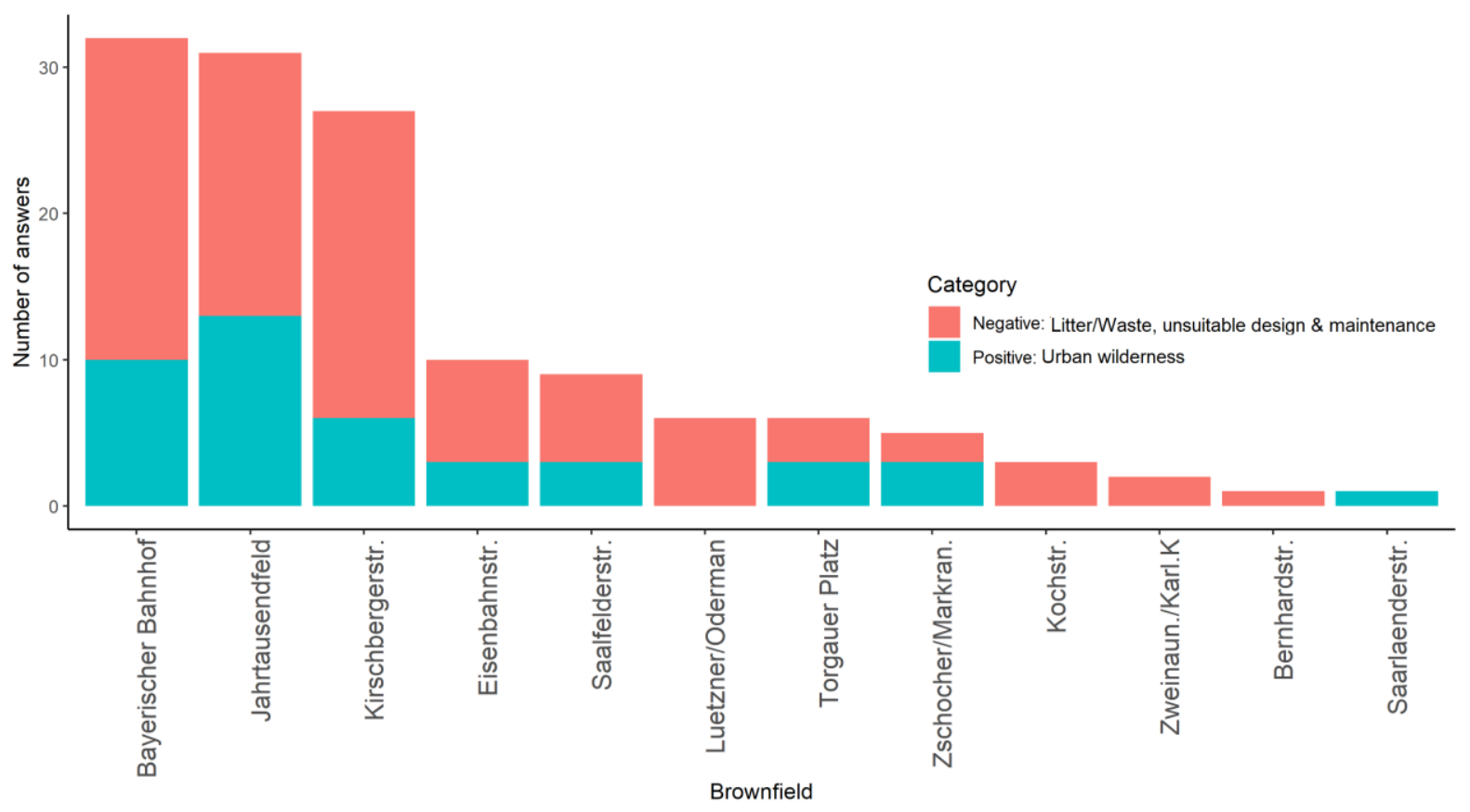

Figure A1.12: Trade-offs between urban wilderness including low maintenance as benefit (positive) and disturbances (negative) due to litter/waste and insufficient management on 12 urban brownfields, where these benefits and disturbances/disservices were specified (categorized answers from open question). 


\begin{tabular}{|c|c|c|c|c|c|c|c|c|c|c|c|c|c|c|c|c|c|c|c|c|c|c|c|c|c|c|c|c|}
\hline \multirow[b]{2}{*}{$\begin{array}{l}\text { Confidence } \\
\text { interval limit }\end{array}$} & \multicolumn{2}{|c|}{$\begin{array}{l}\text { Gardening \& } \\
\text { environmental } \\
\text { education }\end{array}$} & \multicolumn{2}{|c|}{\begin{tabular}{|l|} 
Green \\
landscape/ \\
aesthetics \\
\end{tabular}} & \multicolumn{2}{|c|}{\begin{tabular}{|l|l|} 
Natural \\
elements
\end{tabular}} & \multicolumn{2}{|c|}{\begin{tabular}{|l} 
Regulating \\
ecosystem \\
services \\
\end{tabular}} & \multicolumn{2}{|c|}{$\begin{array}{l}\text { Sense of } \\
\text { place }\end{array}$} & \multicolumn{2}{|c|}{\begin{tabular}{|l|} 
Social \& \\
cultural \\
interactions \\
\end{tabular}} & \multicolumn{2}{|c|}{ Urban wilderness } & \multicolumn{2}{|c|}{ Art \& buildings } & \multicolumn{2}{|c|}{ Dog-friendly } & \multicolumn{2}{|c|}{ Infrastructure } & \multicolumn{2}{|c|}{\begin{tabular}{|l|}
$\begin{array}{l}\text { Park design \& } \\
\text { maintenance }\end{array}$ \\
\end{tabular}} & \multicolumn{2}{|c|}{ Seclusion } & \multicolumn{2}{|c|}{$\begin{array}{l}\text { Size/ availability } \\
\text { \& location }\end{array}$} & \multicolumn{2}{|c|}{ Sport facilities } \\
\hline & 0.05 & 0.95 & 0.05 & 0.95 & 0.05 & 0.95 & 0.05 & 0.95 & 0.05 & 0.95 & 0.05 & 0.95 & 0.05 & 0.95 & 0.05 & 0.95 & 0.05 & 0.95 & 0.05 & 0.95 & 0.05 & 0.95 & 0.05 & 0.95 & 0.05 & 0.95 & 0.05 & 0.95 \\
\hline $\begin{array}{l}\text { Gardening \& } \\
\text { environmental } \\
\text { education }\end{array}$ & 1 & 1 & -0.52 & 0.2 & \begin{tabular}{|l|}
-0.17 \\
\end{tabular} & 0.6 & -0.44 & 0.5 & -0.4 & 0.41 & 0.09 & 0.72 & \begin{tabular}{|l|}
-0.43 \\
\end{tabular} & -0.12 & -0.59 & -0.22 & -0.23 & 0.57 & -0.17 & 0.57 & -0.02 & 0.59 & -0.24 & 0.45 & -0.25 & 0.47 & \begin{tabular}{|l}
0.01 \\
\end{tabular} & $\mid 0.71$ \\
\hline $\begin{array}{l}\text { Green } \\
\text { landscape/ } \\
\text { aesthetics }\end{array}$ & -0.53 & 0.19 & 1 & 1 & \begin{tabular}{|l|}
-0.48 \\
\end{tabular} & 0.59 & -0.23 & 0.67 & -0.65 & 0.23 & -0.44 & 0.52 & $\mid-0.03$ & 0.6 & -0.15 & 0.67 & -0.13 & 0.67 & -0.15 & 0.72 & -0.32 & 0.49 & -0.29 & 0.55 & -0.53 & 0.5 & -0.33 & $\mid 0.57$ \\
\hline $\begin{array}{l}\text { Natural } \\
\text { elements }\end{array}$ & -0.22 & 0.59 & -0.44 & $\mid 0.61$ & 1 & 1 & -0.18 & 0.69 & -0.35 & 0.59 & -0.56 & 0.51 & -0.21 & 0.49 & -0.61 & 0.12 & -0.18 & 0.6 & -0.25 & 0.72 & -0.46 & 0.37 & -0.11 & 0.63 & -0.47 & 0.43 & \begin{tabular}{|l|} 
\\
\end{tabular} & 0.55 \\
\hline $\begin{array}{l}\text { Regulating } \\
\text { ecosystem } \\
\text { services }\end{array}$ & -0.47 & 0.53 & -0.21 & 0.68 & \begin{tabular}{|l|}
-0.14 \\
\end{tabular} & 0.69 & 1 & 1 & -0.58 & 0.18 & -0.71 & 0.1 & -0.21 & 0.38 & -0.18 & 0.56 & 0.04 & 0.74 & -0.58 & 0.2 & -0.41 & 0.41 & 0.18 & 0.76 & -0.52 & 0.17 & -0.68 & 0.29 \\
\hline Sense of place & -0.38 & 0.41 & -0.66 & 0.23 & \begin{tabular}{|l|}
-0.33 \\
\end{tabular} & 0.59 & -0.59 & 0.17 & 1 & 1 & -0.3 & 0.59 & -0.52 & 0.07 & -0.71 & -0.17 & -0.47 & 0.35 & -0.42 & 0.49 & -0.65 & 0.11 & -0.34 & 0.43 & -0.48 & 0.42 & $\mid-0.3$ & 0.62 \\
\hline $\begin{array}{l}\begin{array}{l}\text { Social \& } \\
\text { cultural } \\
\text { interactions }\end{array} \\
\end{array}$ & 0.1 & 0.73 & -0.43 & 0.5 & \begin{tabular}{|l|}
-0.55 \\
\end{tabular} & 0.51 & -0.7 & 0.08 & -0.32 & 0.59 & 1 & 1 & \begin{tabular}{|l|}
-0.72 \\
\end{tabular} & \begin{tabular}{|l|}
-0.22 \\
\end{tabular} & \begin{tabular}{|l|}
-0.79 \\
\end{tabular} & \begin{tabular}{|l|}
-0.3 \\
\end{tabular} & -0.4 & 0.49 & 0.57 & 0.92 & -0.34 & \begin{tabular}{|l|l|}
0.57 \\
\end{tabular} & -0.55 & 0.26 & -0.16 & 0.63 & 0.71 & 0.93 \\
\hline $\begin{array}{l}\text { Urban } \\
\text { wilderness } \\
\end{array}$ & -0.42 & -0 & -0.05 & 0.57 & \begin{tabular}{|l|}
-0.19 \\
\end{tabular} & 0.48 & -0.22 & 0.4 & -0.5 & 0.08 & -0.71 & -0.21 & 1 & 1 & 0.28 & 0.83 & \begin{tabular}{|l|l|}
-0.4 \\
\end{tabular} & 0.47 & -0.44 & 0.19 & -0.41 & 0.47 & \begin{tabular}{|l|l|}
-0.37 \\
-0.37 \\
\end{tabular} & \begin{tabular}{|l|l}
0.57 \\
\end{tabular} & -0.59 & 0.45 & -0.65 & \begin{tabular}{|l|}
0.27 \\
\end{tabular} \\
\hline $\begin{array}{l}\text { Art \& } \\
\text { buildings }\end{array}$ & -0.62 & -0.22 & -0.17 & 0.66 & -0.6 & 0.11 & -0.18 & 0.55 & -0.73 & \begin{tabular}{|l|}
-0.18 \\
\end{tabular} & -0.8 & -0.31 & 0.3 & 0.84 & 1 & 1 & -0.31 & 0.53 & -0.68 & 0.04 & -0.56 & 0.44 & -0.4 & 0.39 & -0.76 & 0.31 & -0.78 & -0.04 \\
\hline Dog-friendly & -0.23 & 0.55 & -0.11 & 0.66 & -0.15 & 0.57 & 0.01 & 0.75 & -0.47 & 0.34 & -0.43 & 0.51 & -0.33 & 0.51 & -0.28 & 0.51 & 1 & 1 & -0.33 & 0.5 & -0.19 & 0.63 & 0.55 & 0.89 & -0.66 & 0.13 & -0.35 & 0.51 \\
\hline Infrastr & -0.14 & 0.56 & -0.17 & 0.71 & \begin{tabular}{|l|}
-0.28 \\
\end{tabular} & 0.7 & -0.6 & 0.18 & -0.4 & 0.48 & 0.57 & 0.92 & -0.42 & 0.21 & -0.68 & 0.02 & -0.36 & 0.53 & 1 & 1 & -0.34 & 0.5 & -0.43 & 0.38 & 0.03 & 0.69 & 0.44 & 0.88 \\
\hline $\begin{array}{l}\text { Park design \& } \\
\text { maintenance }\end{array}$ & -0.01 & 0.59 & -0.33 & 0.5 & \begin{tabular}{|l|}
-0.45 \\
\end{tabular} & 0.36 & -0.39 & 0.42 & -0.65 & 0.1 & -0.3 & 0.59 & -0.42 & 0.47 & -0.55 & 0.46 & -0.2 & 0.62 & -0.33 & 0.52 & 1 & 1 & \begin{tabular}{|l|}
-0.08 \\
\end{tabular} & 0.64 & 0.11 & 0.78 & -0.43 & 0.36 \\
\hline Seclusion & -0.26 & 0.45 & -0.28 & 0.56 & \begin{tabular}{|l|}
-0.09 \\
\end{tabular} & 0.62 & 0.18 & 0.77 & -0.36 & 0.46 & -0.56 & 0.28 & -0.42 & 0.56 & -0.37 & 0.41 & 0.55 & 0.88 & -0.4 & 0.39 & -0.04 & 0.61 & 1 & 1 & -0.41 & 0.43 & -0.52 & 0.34 \\
\hline $\begin{array}{l}\text { Size/ } \\
\text { availability \& } \\
\text { location }\end{array}$ & -0.25 & 0.45 & -0.52 & 0.52 & -0.44 & 0.48 & -0.54 & 0.19 & -0.51 & 0.38 & -0.15 & 0.62 & \begin{tabular}{|l}
-0.6 \\
\end{tabular} & \begin{tabular}{|l|l|}
0.59 \\
\end{tabular} & -0.75 & \begin{tabular}{|l|l} 
\\
\end{tabular} & -0.66 & 0.11 & 0.05 & \begin{tabular}{|l}
0.68 \\
\end{tabular} & 0.11 & \begin{tabular}{|l}
0.77 \\
\end{tabular} & -0.38 & 0.43 & 1 & 1 & -0.28 & 0.6 \\
\hline Sport facilities & 0.04 & 0.74 & -0.31 & 0.55 & \begin{tabular}{|l|}
-0.51 \\
\end{tabular} & 0.53 & -0.67 & 0.28 & -0.29 & 0.61 & 0.7 & 0.93 & -0.65 & -0.27 & -0.78 & -0.05 & -0.35 & 0.57 & 0.44 & 0.87 & -0.48 & 0.39 & -0.52 & 0.3 & -0.27 & \begin{tabular}{|l|l|} 
& 0.61
\end{tabular} & & 1 \\
\hline
\end{tabular}

Table A1.4: Lower and upper confidence intervals for 1000 bootstrapped correlation coefficients for weighted Spearman's rank-correlation of benefits in urban parks. Confidence intervals that do not include zeros (= are below or above zero) are suggesting significant correlations $(p<0.05)$. 


\begin{tabular}{|c|c|c|c|c|c|c|c|c|c|c|c|c|c|c|c|c|c|c|}
\hline \multirow{2}{*}{$\begin{array}{l}\text { Confidence } \\
\text { interval limit }\end{array}$} & \multicolumn{2}{|c|}{$\begin{array}{l}\text { Green landscape/ } \\
\text { aesthetics }\end{array}$} & \multicolumn{2}{|c|}{ Natural elements } & \multicolumn{2}{|c|}{$\begin{array}{l}\text { Social \& cultural } \\
\text { interactions }\end{array}$} & \multicolumn{2}{|c|}{ Urban wilderness } & \multicolumn{2}{|c|}{ Dog-friendly } & \multicolumn{2}{|c|}{$\begin{array}{l}\text { Freedom/no } \\
\text { regulations }\end{array}$} & \multicolumn{2}{|c|}{ Infrastructure } & \multicolumn{2}{|c|}{ Seclusion } & \multicolumn{2}{|c|}{$\begin{array}{l}\text { Size/ availability } \\
\text { \& location }\end{array}$} \\
\hline & 0.05 & 0.95 & 0.05 & 0.95 & 0.05 & 0.95 & 0.05 & 0.95 & 0.05 & 0.95 & 0.05 & 0.95 & 0.05 & 0.95 & 0.05 & 0.95 & 0.05 & 0.95 \\
\hline $\begin{array}{l}\text { Green landscape/ } \\
\text { aesthetics }\end{array}$ & 1 & 1 & -0.3 & 0.87 & -0.42 & 0.86 & -0.27 & 0.88 & 0.03 & 0.96 & -0.01 & 0.93 & -0.52 & 0.75 & 0.2 & 0.95 & -0.34 & 0.86 \\
\hline Natural elements & -0.33 & 0.84 & 1 & 1 & -0.45 & 0.81 & -0.18 & 0.89 & -0.14 & 0.99 & -0.02 & 0.95 & -0.74 & 0.26 & -0.55 & 0.72 & -0.24 & 0.91 \\
\hline $\begin{array}{l}\text { Social \& cultural } \\
\text { interactions }\end{array}$ & -0.43 & 0.85 & -0.37 & 0.82 & 1 & 1 & -0.12 & 0.95 & -0.32 & 0.91 & 0.01 & 0.95 & -0.26 & 0.91 & -0.33 & 0.94 & 0.09 & 0.94 \\
\hline Urban wilderness & -0.16 & 0.89 & -0.18 & 0.88 & -0.16 & 0.93 & 1 & 1 & 0.09 & 0.97 & 0.73 & 1 & -0.61 & 0.72 & -0.12 & 0.91 & 0.39 & 0.97 \\
\hline Dog-friendly & -0.05 & 0.95 & -0.16 & 0.98 & -0.26 & 0.91 & 0.14 & 0.97 & 1 & 1 & 0.31 & 0.99 & -0.74 & 0.6 & 0.2 & 0.94 & -0.06 & 0.97 \\
\hline $\begin{array}{l}\text { Freedom/ no } \\
\text { regulations }\end{array}$ & -0.02 & 0.95 & 0 & 0.95 & 0.06 & 0.95 & 0.69 & 1 & 0.31 & 0.99 & 1 & 1 & -0.61 & 0.66 & -0.02 & 0.9 & 0.59 & 0.97 \\
\hline Infrastructure & -0.51 & 0.72 & -0.75 & 0.17 & -0.25 & 0.91 & -0.56 & 0.72 & -0.77 & 0.57 & -0.61 & 0.62 & 1 & 1 & -0.44 & 0.74 & -0.59 & 0.72 \\
\hline Seclusion & 0.18 & 0.95 & -0.55 & 0.69 & -0.32 & 0.95 & -0.07 & 0.9 & 0.19 & 0.94 & -0.09 & 0.88 & -0.5 & 0.75 & 1 & 1 & -0.33 & 0.83 \\
\hline $\begin{array}{l}\text { Size/ availability } \\
\text { \& location }\end{array}$ & -0.35 & 0.85 & -0.23 & 0.92 & 0.08 & 0.94 & 0.31 & 0.97 & -0.12 & 0.96 & 0.61 & 0.97 & -0.59 & 0.69 & -0.34 & 0.85 & 1 & \\
\hline
\end{tabular}

Table A1.5: Lower and upper confidence intervals for 1000 bootstrapped correlation coefficients for weighted Spearman's rank-correlation of benefits in green brownfields. Confidence intervals that do not include zeros (= are below or above zero) are suggesting significant correlations $(p<0.05)$. 